\title{
EL RÉGIMEN JURÍDICO DEL APROVECHAMIENTO DE PASTOS, HIERBAS Y RASTROJERAS
}

\author{
Ángel SÁNCHEZ HERNÁNDEZ \\ DOCTOR EN DERECHO \\ PROFESOR TITULAR E.U. DE DERECHO CIVIL \\ UNIVERSIDAD DE LA RIOJA
}

s $\quad$ u m a $\mathbf{r}$ i o

I. Introducción. I. Antecedentes históricos de la ordenación del aprovechamiento de pastos. 2. Naturaleza jurídica de la figura «del aprovechamiento de pastos». II. La regulación del aprovechamiento de pastos en el Código civil. I. Artículo 6oo. 2. Artículo 6oI. 3. Artículo 602. 4. Artículo 603. III. La legislación especial sobre aprovechamiento de pastos. I. Legislación estatal especial en materia de pastos. 2. Legislación autonómica especial sobre aprovechamiento de pastos, hierbas y rastrojeras. IV. La Ley $7 / 2000$, de 23 de noviembre de 2000 , de ordenación del aprovechamiento de pastos, hierbas y rastrojeras de la comunidad autónoma de Castillla-La Mancha. I. Objeto de la Ley y ámbito de aplicación. 2. La jerarquía de fuentes. 3. La organización administrativa. 3.I. Comisión local de pastos. 3.2. Comisiones provinciales de pastos. 3.3. Órganos unipersonales. 4. De las ordenanzas y del aprovechamiento de pastos. 5. Aprovechamiento de los pastos. 6. Aislamiento de ganado. 7. Régimen económico del aprovechamiento de pastos. 8. Impugnación de los acuerdos. 9. Régimen sancionador. Io. Disposiciones adicionales, transitorias y finales. V. A modo de conclusión: la dispensable legislación especial de ordenación de pastos, hierbas y rastrojeras.

\section{Introducción.}

I. Antecedentes históricos de la ordenación del aprovechamiento de pastos.

La ganadería ha constituido una importante riqueza patria. Desde épocas remotas, el pastoreo fue una ocupación fundamental de los pobladores de la Península Ibérica ${ }^{\mathrm{I}}$.

I Sobre el particular vide a Costa MARTíneZ, T. El Honrado Concejo de la Mesta y la Asociación 
No se conocen normas reguladoras de los aprovechamientos de pastos en la organización de los primeros pueblos de la Península Ibérica. No obstante cabe determinar el régimen de estos aprovechamientos por medio del tipo de propiedad existente en esos primeros tiempos. Se trataba de una «propiedad» de una parte vaga -de toda la tribu sobre los territorios reservados para la caza o los pastos-, y de otra, inestable, debido a los desplazamientos frecuentes que entrañaba la vida nómada. La forma de propiedad existente constituía un régimen comunal, cuyo objetivo primordial era el aprovechamiento de pastos, que a diferencia del cultivo agrícola, no necesita de determinación de parcelas concretas ${ }^{2}$. En suma, en este periodo, los pastos, constituyen uno de los primeros aprovechamientos del suelo comunal, y a falta de normas escritas, estos aprovechamientos, que eran colectivos, estuvieron regulados por la costumbre, por aquellas nuestras costumbres que reconocieron la propiedad comunal y el aprovechamiento en común de estos frutos de la tierra ${ }^{3}$.

Durante la dominación romana, se produce el progreso del cultivo y la individualización de la propiedad, pero quedaron siempre pastos a pesar del decrecimiento de los terrenos comunales al perfilarse otros aprovechamientos agrícolas, delimitándose así el territorio común en tierras laborables y prados o bosques. A pesar de estas desmembraciones impuestas por el progresivo cultivo de las tierras e individualización de la propiedad, quedaron siempre pastos en extensión más reducida que implican para su aprovechamiento utilizar nuevas formas, en consonancia con el régimen imperante ${ }^{4}$.

Los visigodos, al llegar a España, dejan subsistentes usos y formas de propiedad que eran corrientes entre los pueblos primitivos. En la propia organización germánica se observa la supervivencia de la forma comunal de propiedad junto a las formas primitivas de propiedad celtibérica. En sus primeras ocupaciones, los germanos se posesionaban, por grupos, de un territorio determinado para establecerse en él y cultivarlo. Si bien la propiedad empieza siendo íntegramente colectiva de la tribu, por virtud de las distribuciones sucesivas, parte de la propiedad pasa a ser privada. Pero junto a la propiedad privada ${ }^{5}$, está la propiedad comunal accesoria y complementaria a las tierras cultivables, que se denominaba «Campi vacantes», de aprovechamiento común en uso a vecinos y forasteros ${ }^{6}$.

General de Ganaderos del Reino, I273-I929, Edic. de I936.

${ }^{2}$ Para AlTAMiRA, Historia de la propiedad comunal, Madrid, I929, I p.275, la comunal, es la forma de propiedad que primero se presenta en la historia de los pueblos. Instituciones primitivas de Derecho celtibérico contemplaban aprovechamientos en régimen colectivo, siguiendo un principio de reparto por familias -comunión familiar- de tierras laborables.

${ }^{3}$ Gilarranz De Frutos, L., Nueva Ordenación de Pastos, Hierbas y Rastrojeras, Librería General, Victoriano Suárez, Madrid, I954, p. 5: «Las grandes extensiones desérticas que existían en aquella época si no eran aprovechadas continuamente, especialmente las situadas al lado de los pueblos o campamentos, revertían a las tribus en calidad de tierras comunales. Y siendo el primer aprovechamiento del suelo en estas extensiones comunales los pastos, es natural que, a falta de normas escritas, la costumbre regulara estos aprovechamientos colectivos».

${ }^{4}$ Gilarranz De Frutos, L., Nueva Ordenación de Pastos, Hierbas y Rastrojeras, Librería General, Victoriano Suárez, Madrid, I954, p. 6. NIETO, A., Ordenación de pastos, hierbas y rastrojeras, T.I., Junta Provincial de fomento pecuario de Valladolid, Valladolid, pp. 56 y 57, recuerda como en la época de colonización romana se ideó un tipo de propiedad y aprovechamiento de pastos denominado Compascua que buscaba una armonización y equilibrio entre la actividad agrícola y pecuaria, que no fue una realidad en todos los territorios.

${ }^{5}$ Liber Iudiciorum, VIII, 5,5.

${ }^{6}$ Transhumantes denominados «iter agentes». - Liber VII. IV, 26 Antiqua del liber. 
En las tierras privadas dedicadas al cultivo se distingue entre tierras de secano y huertas. En éstas, nadie que no sea el propietario puede entrar. En las tierras de secano, cabe su aprovechamiento por los ganaderos, una vez levantadas las cosechas y hasta el momento de la nueva siembra.

La propiedad comunal, normalmente distante del poblado, quedaba su aprovechamiento para cualquiera a quien interesase, fundamentalmente forasteros, ya que no ocasionaba ningún perjuicio7. El campo común -los pastos y los montes- continuarán revistiendo el carácter de propiedad colectiva del grupo ${ }^{8}$.

Si bien los visigodos dejaron indivisos los montes y pastos comunes, este uso comunal desaparece con la invasión de los árabes, reapareciendo con la reconquista, mediante las concesiones de terreno que hacen los Reyes a los pueblos. La invasión de los árabes supuso un cambio en la naturaleza jurídica de la propiedad, puesto que la propiedad musulmana, a diferencia de la romana, daba preferencia a la posesión y al uso inmediato de la tierra sobre el derecho de propiedad, lo que influyó en la persistencia en la ganadería de los ganados trashumantes.

Si bien ya con anterioridad a los primeros tiempos de la Reconquista, existía la propiedad privada, se mantuvo la primitiva forma colectiva en los bosques, montes y prados, quedando como un antiguo vestigio el derecho de pasto que tenían los habitantes del territorio hasta en las fincas de dominio privado, una vez levantado el fruto?.

Del siglo VIII al siglo XIII, las comunidades cristianas del norte reviven vestigios del régimen visigodo que les llegaron a través de costumbres, no conociéndose norma escrita estable que determine el régimen pecuario ante el fraccionamiento de la zona cristiana en distintos reinos. En la Edad Media las disposiciones sobre pastos, se caracterizan por el perjuicio local existente contra la propiedad e incluso en algunos casos, en la ocupación temporal de los pastos por los forasteros ${ }^{\text {IO }}$. Ante las constantes guerras, que resultaban incompatibles con la explotación agrícola, los monarcas conceden privilegios de tener acceso a los terrenos comunales con la advertencia frecuente de que no traspasaran los límites de las dehesas, trigales, huertos, viñedos o prados, que siempre fueran respetados ${ }^{\mathrm{II}}$.

El siglo XIII está dominado por los textos legales de Alfonso $\mathrm{X}$ «El Sabio» ${ }^{\mathrm{12}}$ y por la aparición del Concejo de la Mesta ${ }^{\mathrm{I3}}$. En las Partidas de Alfonso X «El Sabio», se consignaban

\footnotetext{
${ }^{7}$ PÉREZ PUJOL, Historia de las instituciones políticas de la España goda, Valencia I896, T.IV, pp.346 y 352

${ }^{8}$ AZCÁRATE, Ensayo sobre la historia del derecho de propiedad, Madrid, I879, II, p. I57 y ss.

${ }^{9}$ AZCÁRATE, Ensayo sobre la historia del derecho de propiedad, Madrid, i879, II, p. 88.

ro Sobre el particular vide a KLEIN, J., La Mesta, Edc. I936. ElIAS PASTOR, L.V. y Otros, Estudio sobre cultural migratorias pastoriles, Etnografía Española, T. 9, Ministerio de Cultura, I995, pp. 9-49.

" GilarRanz De FrUTOS, L., Nueva Ordenación de Pastos, Hierbas y Rastrojeras, Librería General , Victoriano Suárez, Madrid, I954, p. 7.

${ }^{12}$ Ya en Fuero Real, promulgado el año I225 se contiene una disposición de mucha importancia con la que se enlaza la antigua legislación de los iter agentes visigóticos. Concretamente es la Ley 4 del Tít. 6 del Libro IV del fuero Real dice así : «Los viandantes pueden meter sus e los otros ganados a pacer en los lugares que no son cerrados ni defendidos y pueden y descargar y folgar por un día o por otros dos al más, si el dueño del lugar gelo otorgare»

${ }^{13}$ Organización de propietarios de ovejas del Reino, en la que con el tiempo existió una excesiva preponderancia de los ganaderos trashumantes, lo que hizo que esta organización llegase a convertirse
} 
cláusulas para favorecer los intereses de los trashumantes, pero insistiendo en que las dehesas locales y los terrenos propios o del común tenían que ser respetados por aquéllos ${ }^{\mathrm{T} 4}$. En las Cartas Reales otorgadas a los ganaderos se definían las relaciones de los trashumantes con los propietarios de las fincas cercadas, dando lugar a los primeros fueros de la Mesta ${ }^{15}$. Pocos años después de completarse las Partidas, aparecen los primeros Fueros de la Mesta ${ }^{16}$ de 1273 y 1276.

Con los Reyes Católicos, y teniendo presente que la lana regularizaba nuestra balanza de pagos, la Mesta se impuso sobre los Fueros de las ciudades que durante la Edad Media, normalmente, hicieron prevalecer sus derechos frente a los confusos y amplios privilegios de los ganaderos trashumantes. De las leyes promulgadas en época de los Reyes Católicos a favor de la ganadería mesteña, la que más menoscabó otros intereses legítimos, fue la de «posesión», por cuya virtud se podían disfrutar los pastos de un terreno mediante el pago de la renta del primitivo arriendo a favor de los Hermanos de la Mesta.

En los reinados posteriores se sigue la misma tendencia, fundamentalmente por dos razones. La primera por la inercia administrativa. La segunda por la penuria del tesoro que se fijo para mejorar sus tributos en el fortalecimiento de la organización mesteña. En estos siglos, la legislación pastueña se asienta sobre dos instituciones: La Posesión y las Derrotas.

La Posesión, institución de aplicación hasta el Decreto de I8I3, fue un enmarañado privilegio $^{\text {17 }}$ «y que no debe confundirse con la posesión de Derecho civil- que estaba destinada

en un instrumento a su exclusivo servicio. Sobre la Mesta vide a NIETO, A., Ordenación de Pastos, Hierbas y rastrojeras, Tomo I, Junta Provincial de Fomento Pecuario de Valladolid, Valladolid, I959, pp. I34 a I82. Los privilegios de que gozaba la ganadería -tuvieron estado legal desde Alfonso X y fueron creciendo de tal modo que ya en el S. XV, merced a disposiciones de carácter particular -que se interpretaron y aplicaron de un modo general-, se estableció la prohibición de cercar las fincas rústicas, quedando sus productos secundarios en beneficio de los ganaderos- (En I778, se reconoció expresamente a los dueños de las fincas la facultad de cercalas -Ley I9, título XIV, libro VII, Nov. Rec-). Para AlTAMIRA, Historia de la propiedad comunal, Madrid, I890, p. 97, al dar a los preceptos legales un carácter general y absoluto, se despojó a los vecinos de muchos pueblos de un derecho legítimo.

${ }^{14}$ Covían, Pastos de facería, en «Enc. Jur. Seix>>, tomo XXIV, p. 464. La interpretación de la Ley I9 del título I8, de la partida $3^{\text {a }}$ del Rey Sabio ha marcado en buena medida la historia ganadera de España y dice así: «Como sepan todos los que esta carta vieren, e que la oyeren, que manda el Rey que los ganados de aquel o de aquellos a quien diera la carta que anden salvos e seguros por todas las partes de sus reinos e pazcan las yerbas e beban las aguas; e non faciendo daño en miesses, nin en viñas, nin en otros lugares acotados; e dando sus derechos do los debieren dar, que ninguno non sea osado de gelos embargar nin gelos contrallar: ca cualquier que lo fiziese pecharía tanto en coto al Rey e al querelloso o el daño doblado».

${ }^{15}$ Las principales dificultades del problema de pastos se solucionaron en esa época con las transacciones colectivas, posesiones, tasas, derrota de mieses, etc., véase CoviÁn, Pastos de facería, en «Enc. Jur. Seix.», tomo XXIV, p. 464.

${ }^{16}$ Así, en el siglo XIII surge una compleja organización dedicada a regular, controlar y proteger la actividad ganadera. La Mesta como organización pastoril dependiente de la Corona regula toda la actividad ganadera hasta comienzos del siglo XIX en que desaparece. Esa incipiente organización no podía imaginar las interpretaciones, que en siglos posteriores, con la protección real y por la habilidad mesteña, habían de darse un día al régimen pastueño. Se hizo una interpretación extensiva de los aprovechamientos a todos los campos, las ovejas se derramaron por todo el territorio nacional, véase a Nieto, A., Ordenación de Pastos, Hierbas y rastrojeras, Tomo I, Junta Provincial de Fomento Pecuario de Valladolid, Valladolid, I959, p. 76.

${ }^{17}$ Tuvo su origen en una sencilla disposición que sólo a fuerza de forzar se amplio su primitivo significado. En las Ordenanzas de la recopilación de MALAPARTIDA, se contendía esa disposición eficaz 
esencialmente a «evitar la competencia entre todos los hermanos de la Mesta» y así repartirse todas las particiones de pastos del Reino. Su esencia no pasa de ser un «título precario sobre los pastos y hierbas que producen los fundos» ${ }^{18}$. Se trata de un privilegio resultado de un conflicto de intereses, en el que la ley toma parte por la manutención de los ganados trashumantes por considerarla como causa pública que prevalece sobre otras. Como consecuencia de este gravamen impuesto sobre las dehesas, se generan restricciones al derecho de propiedad -se priva a los propietarios de libertad al conceder un derecho contra la voluntad de su dueño- en beneficio de la ganadería y la economía ganadera.

En cuanto a las Derrotas de mieses, se trata de una forma de aprovechamiento de los campos por los ganados una vez levantadas las cosechas y hasta el momento de la nueva siembra. Lejos de ser una manifestación del «ius usus inocui» ${ }^{\text {19 }}$, el aprovechamiento de rastrojos, del respigueo $u$ otros restos de la cosecha contra la voluntad del dueño de los campos, va en su perjuicio por cuanto le despoja de un cierto valor económico ${ }^{20}$. Creo que es ocioso recordar como la propiedad concede el derecho a todos los frutos, siendo el aprovechamiento de pastos por extraños, sencillamente un despojo, pues tanto el pasto espontáneo de las tierras -de rastrojo, de barbecho-, o de las espigas y granos caídos sobre ellas son parte de la propiedad de la tierra ${ }^{2 \mathrm{I}}$. Ahora bien, cualquiera que fuere el ropaje jurídico con el que se pretenda explicar, la propiedad afectada por el régimen de Derrotas no reviste forma especial, sino que constituye sencillamente una manifestación normal de la propiedad que por determinadas circunstancias -minifundio y cultivos de secano de un lugar-, adopta una peculiaridad en su aprovechamiento ${ }^{22}$.

Con las reformas agrarias del S. XVIII se prepara un camino que conduce a la

para evitar el regateo en los arriendos: las cuatro cuadrillas de la Mesta -que tenían su sede en Soria, Segovia, Cuenca y León- elegían anualmente un representante que se dirigía a las principales regiones de pastos de Extremadura y Andalucía para arreglar con los propietarios de las tierras las rentas y distribución de las particiones para la próxima estación.

${ }^{\mathrm{r} 8}$ Sobre esta institución vide a NIETO, A., Ordenación de Pastos, Hierbas $y$ rastrojeras, Tomo I, Junta Provincial de Fomento Pecuario de Valladolid, Valladolid, I959, p. 85 y ss.

${ }^{19}$ Considera inaplicable al tema esta teoría BATlle Y VÁZQueZ, M., Derecho Civil, Apéndice a Castán, Registros, Vol. $2^{\circ}$, p. I3.

${ }^{2 \circ}$ Se entendió que las Derrotas constituyen un fenómeno de desmembración del dominio: la comunidad en su origen, propietaria única del suelo, lo tenía destinado en un principio a dos distintos usos y se ha dejado privar de uno, el del cultivo quedando en posesión del otro, el de los pastos. No habiendo los miembros de la colectividad adquirido nunca, ni a título gratuito ni a título oneroso, el otro aprovechamiento, el de los pastos, no pueden pretenderlo para sí, ni pueden decirse despojados por la invasión periódica o regular de sus rastrojeras por el ganado del vecindario. En este sentido CosTA, J., Colectivismo agrario en España, 2a Edc., Madrid, I9I5, p. 508, quien entiende que la colectividad, originaria propietaria única del suelo, entregó a cada uno de los miembros el cultivo de una o más parcelas cada año con la condición de que los rebaños de todo el vecindario siguieran comiendo cuanto no se halle sembrado, sean rastrojos, barbechos o eriales. Un día aquel usufructo o posesión temporal de aquellas parcelas por los vecinos se hace permanente, primero de hecho y después de derecho, individualizándose el dominio: uno privado, el cultivo sin exceder el periodo de la vegetación del cereal, y otro el de los pastos, continuando éste aprovechamiento común de las hierbas para la colectividad.

${ }^{21}$ Jovellanos, G. M., Informe sobre la Ley agraria, Edc. De la Biblioteca Universal, Madrid, I9I7, 2 vol., en el epígrafe «Estorbos políticos o derivados de la legislación. III. Abertura de heredades».

${ }^{22}$ Sobre las Derrotas su desenvolvimiento histórico y la ordenación española hasta el Código civil vide a NiETO, A., Ordenación de Pastos, Hierbas y rastrojeras, Tomo I, Junta Provincial de Fomento Pecuario de Valladolid, Valladolid, I959, pp. I9I a 220. 
desaparición posterior del Honrado Concejo y los privilegios mesteños. Con el triunfo de la doctrina individualista ${ }^{23}$, se abolió en I786 la Ley de «Posesión» y la Ley de II de julio de I8I3 -reestablecida en 6 de septiembre de I893-, considera acotadas y cercadas todas las fincas de propiedad particular, desconociendo las servidumbres de pastos existentes que no se fundasen en título de adquisición válido y legítimo.

Promulgadas las leyes desamortizadoras, ya en la mitad del siglo XIX, desapareció casi por completo la propiedad comunal, pasando ésta al dominio privado ${ }^{24}$.

Tras la Ley de I5 de septiembre de I932, de Reforma Agraria, que paso fugazmente como la segunda República, finalmente, ante la realidad social de la supervivencia de las comunidades de pastos en muchos pueblos, con sus aprovechamientos colectivos por encima de las normas legales ${ }^{25}$, con el deseo de coordinar los intereses agrícolas y ganaderos, de las labranzas y crianzas, que deben guardar una armónica relación, se promulgó la Ley de Pastos, Hierbas y Rastrojeras ${ }^{26}$ de 7 de octubre de 1938 , desarrollada posteriormente por el Reglamento de 8 de enero de I954, al que le sucedió el Reglamento de Pastos. Hierbas y Rastrojeras, aprobado por Decreto 1256/1969, de 6 de junio. A partir de este momento distintas eran la formas de aprovechamiento de pastos y rastrojeras: a) pastos comunales, con base en las tradiciones municipales, y con arreglo a la legislación local y pastueña ${ }^{27}$; b) pastos de propiedad particular, en aquellas fincas que permitan una explotación pecuaria independiente de sus aprovechamientos de pastos durante el año pastoril, dando lugar a un aprovechamiento directo y libre por el propietario, o bien, cederlo en régimen de arrendamiento o aparcería ${ }^{28}$; c) pastos en régimen de concentración, mediante el ejercicio mancomunado de la ganadería -institución consuetudinaria- en virtud del cual todos o algunos de los labradores de una localidad ponen en común los pastos que poseen, reúnen su ganado en un rebaño y lo confían a un solo pastor, al que pagan en proporción al número de cabezas de ganado que posee cada uno y por último d) el régimen especial que coordina los intereses agrícolas y ganaderos, que lejos de quedar a la iniciativa privada su gestión, se encuadra en una gestión administrativa sujeta a un régimen especial, sin que ello implique la desaparición de garantías y derechos particulares ${ }^{29}$.

${ }^{23}$ Siendo destacado precursor JovelLANOS, G. M., Informe sobre la Ley agraria, Edc. de la Biblioteca Universal, Madrid, I9I7, 2 vol.

${ }^{24}$ FLÓREZ De QUIÑONES, V., Comunidad o servidumbre de pastos, Revista de Derecho privado, $\mathrm{n}^{\circ} 237$, I5 de junio de I933, p. I67.

${ }^{25}$ Hecho destacado por Bletran De Heredia, La Comunidad e Bienes en el Derecho Español, I954, a pesar de la especialidad de estos aprovechamientos como una de las formas donde se manifiesta todavía en nuestro Derecho la antigua «comunidad en mano común», de tipo germánico.

${ }^{26}$ Grau Campuzano, Régimen legal de pastos, Madrid, I943.

${ }^{27}$ Artículo 75 del Real Decreto Legislativo 78I/I986, de I8 de abril, por el que se aprueba el texto refundido de las disposiciones legales vigentes en materia de Régimen Local.

\footnotetext{
${ }^{28}$ Véase BERNAL MARTín, Arrendamientos rústicos, Librería General Victoriano Suárez, Madrid i954.

${ }^{29}$ Como por ejemplo los de servidumbres de pastos, artículo 600 a 604 de nuestro Código Civil.
} 
2. Naturaleza jurídica de la figura «del aprovechamiento de pastos».

La inmensa mayoría de los civilistas patrios pasan como sobre ascuas por este problema y a su naturaleza jurídica sólo le dedican alguna somera indicación ${ }^{30}$. El primero de los comentaristas del Código, la consideró como comunidad, basándose en que la preocupación de aquél fue impedir la perpetuidad, facilitar la redención y no hacer permanente el estado de indivisión ${ }^{3 \mathrm{I}}$. MUCIUS SCAEVOLA refiriéndose en este punto, únicamente, a las establecidas con arreglo al Código civil, las cree comunidades de bines, excepto en el caso del artículo 603, que parece regular una servidumbre ${ }^{32}$. Pero, en general, no se olvida que las Partidas la regularon tan sólo como servidumbre ${ }^{33}$.

En cambio, el aprovechamiento (que forma parte de la propiedad de la tierra) por terceros, del pasto de las tierras -de rastrojo o de barbecho- o de las espigas o granos caídos sobre ellas -respigueo- $u$ otros restos de cosecha, regulado en la legislación especial, genera restricciones al derecho de propiedad en beneficio de la ganadería y de la economía ganadera. Por tanto, la naturaleza jurídica de estos aprovechamientos de pastos, hierbas y rastrojeras, pudiera así considerarse como una limitación del dominio por la que se impone al propietario un aprovechamiento de sus pastos, hierbas o rastrojeras a favor de terceros mediante una intervención administrativa amparada en la legislación pastueña. Sabido es que nuestro Código Civil admite la existencia de limitaciones del dominio en la propia definición del artículo 348. El aprovechamiento de pastos, hierbas y rastrojeras, constituirían así, limitaciones impuestas por la Ley a determinados predios que se encuentran en determinadas condiciones, señalando, de paso, las condiciones normales del dominio. Se trata de una

${ }^{30}$ FlóReZ De QuiÑones, V., Comunidad o servidumbre de pastos, Revista de Derecho privado, $\mathrm{n}^{\circ}$ 237, I5 de junio de I933, pp.I7I, I72 y I73.

${ }^{31}$ NAVARro Amandi, Comentarios al Código civil reformado, Madrid, i89o, II, p 346.

${ }^{32}$ Mucius SCAEVola, Código Civil comentado y concordado extensamente, Madrid, ı895, X, p. 6ı6,

${ }^{33}$ Ley 6 , tit. XXXII, Part. $3^{\mathrm{a}}$-, refiriéndose únicamente al caso de la típica pecoris pascendci, que el Derecho romano incluía entre las prediales , BURÓN, Derecho Civil español, Valladolid, I898, II, p.390, que únicamente la define, la clasifica entre éstas. Para VALVERDE, Tratado de Derecho civil español, Valladolid, I925, II, p.382, aunque a primera vista parece una manifestación de la copropiedad, y puede serlo en algún caso, no hay duda de que el hecho de pastar, significa un gravamen, una restricción de la propiedad de otro, y, por consiguiente, es una servidumbre de las que el Código llama personales. SÁNCHEZ RomÁn, Estudios de Derecho civil, Madrid, I900, III, p. 644, sin afirmar nada en concreto, cree que se trata más de una comunidad que de una servidumbre; para DE DIEGO, Instituciones de Derecho civil español, Madrid, I930, I, 385, este instituto tiene algo de especial, porque estos aprovechamientos pueden pertenecer a título de condominio o a título de Derecho real especial, que tiene pronunciadas analogías con la servidumbre. VISO, Lecciones elementales de Derecho Civil, II, Valencia, I885, p. 96, siguió un sistema ecléctico, puesto que la considera como servidumbre; pero cuando mutuamente se debieran este derecho varios condueños -ius compascui o comunidad de pastos-, se tratará de un derecho distinto al de servidumbre. DE BUEN, Notas al curso elemental de Derecho civil, de COLIN Y CAPITANT, II, p. 700, cree que cuando la situación de los diversos propietarios sea la misma , sin que en ninguno de ellos aparezcan las características facultades dominicales, la situación tendrá una gran analogía con el supuesto de un condominio, pero no será un condominio en sentido estricto. MANRESA, Comentarios al Código civil español, Madrid, I920, IV, p. 845, cree que coexisten las dos figuras, con cuya tesis parece estar conforme ISABAL, Enciclopedia Jurídica Española, Barcelona, s.f., XXIV, 467, ya que la considera como servidumbre en cuanto es gravamen, pero cuando son varios los titulares cree que existe comunidad entre ellos, sin alterar aquel carácter. CASTÁn, Derecho civil español común y foral, Madrid, I924, I, 302, cree que puede existir a título de servidumbre o a título de condominio y que en la práctica habrá que atender, en cada caso concreto, al origen, carácter y extensión para resolver las dificultades que se deriven de la afinidad entre ambas figuras. 
limitación legal del dominio en base a la convivencia social que exige la subordinación de los intereses privados -propietarios particulares- a lo intereses generales y colectivos ${ }^{34}$.

\section{La regulación del aprovechamiento de pastos en el Código civil.}

Los artículos 600 a 603 de nuestro Código Civil se refieren al aprovechamiento de pastos y son fruto de la concepción individualista del derecho de propiedad de un Código fiel a su tiempo.

\section{Artículo 600.}

En el artículo 600 se prohíbe constituir comunidades de pastos sobre una universalidad de bienes y a favor de una universalidad de individuos, y se desconocen las que se constituyen por otros títulos que no sea la última voluntad o el contrato ${ }^{35}$.

El precepto obedece al criterio recogido en el artículo 388 del propio Código Civil, que posibilita a todo propietario el cercar sus heredades, sin perjuicio de las servidumbres constituidas sobre las mismas ${ }^{36}$. Además, introduce la novedad de que el establecimiento de la comunidad de pastos, en lo sucesivo, sólo podrá realizarse por concesión expresa de los propietarios de las fincas «en las que se realicen los aprovechamientos-, bien por medio de un contrato o de un acto de última voluntad. Se excluye como medio que pueda dar lugar al aprovechamiento comunitario de pastos la prescripción» artículo I930 del Código Civil.-

El artículo 600 no se aplica a los aprovechamientos anteriores a la entrada en vigor del Código Civil y que fueron reconocidos de acuerdo con la legislación anterior, por la que se regirán ${ }^{37}$. Este precepto genera confusionismo al emplear en el párrafo primero el concepto de «comunidad de pastos» y en el párrafo segundo el término «servidumbre», para referirse a los mismos aprovechamientos. Esa falta de claridad conduce a preguntase sobre la naturaleza jurídica de los aprovechamientos comunitarios de pastos, ¿son una comunidad o por el

${ }^{34}$ Cfr. Castan TobeÑAs, J., Derecho Civil Español, Común y Foral, Tomo 2 ${ }^{\circ}$, Reus, S.A., Madrid, I992, p. 238 y ss. Contrariamente, NIETO, A., Ordenación de Pastos, Hierbas y Rastrojeras, Tomo I, Junta Provincial de Fomento Pecuario de Valladolid, I959, pp. 278 y ss. , considera que se trata de una expropiación atípica del artículo 2 del Decreto de 26 de abril de i957, por el que se aprueba el Reglamento de Expropiación Forzosa.

${ }^{35}$ El precepto se ha contemplado como «fiel reflejo del sentimiento individualista reinante en la época de publicación del Código Civil» y como «una clara manifestación del sentido liberal en la organización de la propiedad inmueble» que reacciona ante los privilegios tradicionalmente otorgados a las asociaciones de ganaderos, vide CuAdrado Iglesias, M., Artículo 6oo, Comentario del Código Civil, Tomo I, Ministerio de Justicia, Madrid, I993, pp. I5I7 y ss.

${ }^{36}$ Como antecedentes legislativos de este artículo se encuentra el Decreto de 8 de agosto de I8I3 sobre acotamiento y cerramiento de fincas rústicas y la Ley 23 de septiembre de 1836 .

${ }^{37}$ Disposición Transitoria I ${ }^{\text {a: }}$ «Se regirán por la legislación anterior al Código los derechos nacidos según ella, de hechos realizados bajo su régimen, aunque el Código los regule de otro modo o no los reconozca» 
contrario una servidumbre $?^{3^{8}}$.

Cuando se trata de aprovechamiento de pastos en terrenos de propiedad privada pueden concurrir ambas figuras, y dependiendo del título constitutivo del aprovechamiento, de su carácter y de su extensión estaremos ante una comunidad o ante una servidumbre.

En el caso de que la titularidad dominical del predio pertenece a uno o varios de los interesados en el aprovechamiento, estamos ante una servidumbre de pastos. En cambio si la titularidad dominical del predio pertenece a la totalidad de quienes se reúnen para disfrutar los aprovechamientos comunitarios, estamos ante la comunidad de pastos ${ }^{39}$.

${ }^{38}$ FLÓREZ DE QUIÑONES, V., Comunidad o servidumbre de pastos, Revista de Derecho privado, $\mathrm{n}^{\circ} 237$, I5 de junio de I933, pp.I7I, I72 y I73 escribe: «La inmensa mayoría de los civilistas patrios pasan como sobre ascuas por este problema y a su naturaleza jurídica sólo le dedican alguna somera indicación. El primero de los comentaristas del Código, en sus breves y agudas acotaciones, la consideró como comunidad, basándose en que la preocupación de aquél fue impedir la perpetuidad, facilitar la redención y no hacer permanente el estado de indivisión» NAVARRO AMANDI, Comentarios al Código civil reformado, Madrid, I89o, II, 346-. MuCius SCAEvolA, Código Civil comentado y concordado extensamente, Madrid, I895, X, p. 6I6, refiriéndose en este punto, únicamente, a las establecidas con arreglo al Código civil, las cree comunidades de bines, excepto en el caso del artículo 603, que parece regular una servidumbre. Pero, en general, no olvidan que las Partidas la regularon tan sólo como servidumbre -Ley 6, tit. XXXII, Part. $3^{a}$-, refiriéndose únicamente al caso de la típica pecoris pascendi, que el Derecho romano incluía entre las prediales. GIRARD, Manuel élémentaire de Droit romain; París, I924, p. 375. Así BURÓN, Derecho Civil español, Valladolid, I898, II, p.390, que únicamente la define, la clasifica entre éstas; para VALVERDE, Tratado de Derecho civil español, Valladolid, I925, II, p.382, aunque a primera vista parece una manifestación de la copropiedad, y puede serlo en algún caso, no hay duda de que el hecho de pastar, significa un gravamen, una restricción de la propiedad de otro, $y$, por consiguiente, es una servidumbre de las que el Código llama personales. SÁnCHEZ RomÁn, Estudios de Derecho civil, Madrid, I9oo, III, p. 644, sin afirmar nada en concreto, cree que se trata más de una comunidad que de una servidumbre; para DE DIEGO, Instituciones de Derecho civil español, Madrid, I930, I, 385, este instituto tiene algo de especial, porque estos aprovechamientos pueden pertenecer a título de condominio o a título de Derecho real especial, que tiene pronunciadas analogías con la servidumbre. DE BUEN, Notas al curso elemental de Derecho civil, de COLIN Y CAPITANT, II, p. 700, cree que cuando la situación de los diversos propietarios sea la misma , sin que en ninguno de ellos aparezcan las características facultades dominicales, la situación tendrá una gran analogía con el supuesto de un condominio, pero no será un condominio en sentido estricto. VISO, Lecciones elementales de derecho civil, II, Valencia, I885, p. 96, siguió un sistema ecléctico, puesto que la considera como servidumbre; pero cuando mutuamente se debieran este derecho varios condueños -ius compascui o comunidad de pastos-, se tratará de un derecho distinto al de servidumbre. MANRESA, Comentarios al Código civil español, Madrid, I920, IV, p. 845, después de alabar la lógica del Código en este punto, cree que coexisten las dos figuras, con cuya tesis parece estar conforme ISABAL, Enciclopedia Jurídica Española, Barcelona, s.f., XXIV, 467, ya que la considera como servidumbre en cuanto es gravamen, pero cuando son varios los titulares cree que existe comunidad entre ellos, sin alterar aquel carácter. CASTÁN, Derecho civil español común y foral, Madrid, I924, I, 302, cree que puede existir a título de servidumbre o a título de condominio y que en la práctica habrá que atender, en cada caso concreto, al origen, carácter y extensión para resolver las dificultades que se deriven de la afinidad entre ambas figuras, y más tarde afirma CASTÁN, Revista de Derecho Privado, Madrid, I932, XIX, p.II3, que no se encuentra el modo de imaginar una comunidad entre el titular del derecho dominical y los titulares de derechos que limitan su dominio, lo que, de otra parte, enervaría los recursos de redención y refundición que pueden realizar la finalidad económica de reconstruir el dominio en su plenitud, finalidad que, influido por su enorme cultura dogmática, encuentra altamente plausible.

${ }^{39}$ Ante la poca claridad del artículo 600, el propio Tribunal Supremo ha abordado la distinción entre «comunidad» y «servidumbre» de pastos en diversas sentencias , antiguas unas, vg. I8 de febrero de I932, otras más recientes, vg. 24 de febrero de I984. 
En relación con el derecho de aprovechamientos de pastos en terrenos de propiedad privada al que se refiere el artículo Goo del Código civil, siguiendo a CUADRADO IGLESIAS ${ }^{40}$, cabe distinguir tres supuestos:

I.) «Varios propietarios poseen en común los productos de sus predios para aprovecharlos conjunta y exclusivamente con ganados de su pertenencia». Existe una reciprocidad de pastos por voluntad de los propietarios de todos y cada unos de los fundos, a favor de todos y cada uno de los ellos: cada propietario tiene derecho de llevar sus propios animales a los fundos de los otros. Se trata de una comunidad de pastos que en nada afecta a las titularidades dominicales que siguen perteneciendo a cada uno de los propietarios.

También se constituye una comunidad de pastos, siendo el soporte físico un terreno en copropiedad: el fundo está proindiviso y los copropietarios aprovechan sus pastos con sus ganados $^{41}$.

II.) Un segundo supuesto se produce cuando uno o varios propietarios aprovechan con sus ganados los pastos de sus fincas en concurrencia con ganados de personas extrañas a la titularidad dominical de los predios. En el aprovechamiento de pastos coexisten la comunidad y la servidumbre: Respecto de los que son propietarios de fundo, existe comunidad, no de la propiedad, sino de disfrute ya que el aprovechamiento se lleva a cabo conjuntamente. En cambio, de los que sin ser propietarios del fundo concurren al aprovechamiento con quienes son propietarios, existe una servidumbre de pastos, ejercida en común si existe una pluralidad de beneficiarios, al resultar gravada la finca con este aprovechamiento de los no propietarios.

Las servidumbres de pastos, son servidumbres de tipo personal y de naturaleza discontinua. Personales ya que no existe un predio dominante, constituyéndose a favor de una o más personas o de una comunidad a quienes no pertenece la finca gravada ${ }^{42}$; de naturaleza discontinua ya que requieren para su aprovechamiento la actividad del hombre ${ }^{43}$.

III.) En tercer y último lugar, cabe que los pastos de los terrenos de particulares sean aprovechados íntegramente por ganados de personas a quienes no pertenece la propiedad de las fincas. Estamos ante una servidumbre de pastos, generada bien por voluntad de los

${ }^{40}$ Cuadrado Iglesias, M., Artículo 6oo, Comentario del Código Civil, Tomo I, Ministerio de Justicia, Madrid, I993, p. I5I9.

${ }^{4 \mathrm{I}}$ Dentro de la modalidad de comunidad de pastos podemos distinguir dos modalidades. Una de tipo romano y otra de tipo germánico. Se trata de una comunidad de tipo romano o por cuotas partes, si los propietarios aprovechan con sus ganados los pastos de sus fincas o cuando los pastos se aprovechan por quienes no son propietarios de las fincas si su aprovechamiento deriva de su consideración «utili singuli».

En cambio la comunidad de pastos es de tipo germánico, si el derecho de aprovechamiento de pastos se deriva de la consideración de «utis cives» -vg. ser vecinos de un determinado municipio-, y además existe : a) una variedad del número de beneficiarios, b) una ausencia de cuotas como en la modalidad romana, c) la inalienabilidad de la participación, d) la intransmisibilidad a los herederos y d) no proceder la actio communi dividundo. Se encuentra en esta modalidad de tipo germánico el caso de una comunidad de pastos cuyo aprovechamiento está constituido a favor de aquellos en cada momento formen parte del colectivo vecinal.

${ }^{42}$ OSSORIO Y MORALES, A., Las servidumbres personales. Madrid, I936, p. 96.

${ }^{43}$ Sobre las servidumbres discontinuas vide a LACRUZ BERDEJO,J.L., Usucapión de las servidumbres discontinuas o no aparentes, Revista General de Legislación y Jurisprudencia, I954. 
propietarios de las fincas, o bien al margen de dicha voluntad. Concretamente se trata de una servidumbre de pastos ejercida en común o si se quiere servidumbre de comunidad de pastos.

\section{Artículo GoI.}

El precepto se refiere a una comunidad de pastos concreta en terrenos públicos. Se trata del común aprovechamiento de pastos en unos terrenos comunales ${ }^{44} \mathrm{y}$ comunidades de tierra fundamentalmente, regulados en legislación administrativa que ha respetado el derecho consuetudinario.

El aprovechamiento y disfrute de bienes comunales se efectuará, si es posible en régimen de explotación común ${ }^{45}$ por los vecinos ${ }^{46}$. Cuando no es posible el régimen de explotación común, se adoptará una de las siguientes formas de aprovechamiento:

a) Aprovechamiento según costumbre o reglamentación local, ajustándose respectivamente a normas consuetudinarias o bien a las que cuando proceda apruebe la Comunidad Autónoma.

b) Adjudicación por lotes o suertes a los vecinos en proporción directa al número de personas que tengan a su cargo e inversa a su situación económica ${ }^{47}$.

c) Adjudicación mediante precio, que habrá de ser autorizada por la Comunidad Autónoma, efectuándose mediante subasta pública siendo preferentes los pastores vecinos.

3. Artículo 602.

Este precepto referido a la comunidad de pastos, se ocupa del cercado de una finca como medio que puede utilizarse por los comuneros para salir de tal comunidad. El cerramiento de una finca la individualiza y además la libera de la comunidad de pastos. En cuanto al significado de la frase «in fine» de este primer apartado, «quedarán, sin embargo, subsistentes las demás servidumbres que sobre la misma estuviesen establecidas», significa que el cerramiento individualiza la finca a la vez que la liberaliza de la comunidad de pastos pero no de una inexistente servidumbre de pastos-, eso si, subsistiendo las servidumbres que

44 Los bienes comunales son bienes de dominio público, de propiedad municipal, cuyo aprovechamiento y disfrute corresponde a los vecinos -artículo 79.3 de la Ley Reguladora de las Bases de régimen Local de 2 de abril de I985 y artículo 2.3 del Reglamento de Bienes de las Entidades Locales de I3 de junio de I986-, sin que existan cuotas determinadas- comunidad de tipo germánico-. Según el artículo 5 del este último texto legal, se trata de bienes inalienables inembargables e imprescriptibles, no estando sujetos a tributo alguno.

${ }^{45}$ Artículo 94.I del Reglamento de bienes de las Entidades Locales de I3 de junio de I986.

${ }^{46}$ Esta forma de aprovechamiento de pastos es recogida en el artículo 62 del Reglamento de pastos de i969. De la que constituye una modalidad recogida es ese precepto y regulada en el artículo 36 del Reglamento de Pastos de I969, la dula o piara concejil: reunión de ganados de los vecinos de un termino municipal para el aprovechamiento en común de los pastos.

${ }^{47}$ Artículo 97 del Reglamento de bienes de las Entidades Locales de I3 de junio de I986. 
graven la finca ${ }^{48}$.

El artículo 602 trata de impedir el acceso de ganados a la finca cercada, pero no sólo por los medios que arbitra el artículo -tapia o seto-, sino que también deben considerarse aplicables los medios aludidos en el artículo 388 del Código Civil , con el que ha de relacionarse: paredes o zanjas y cualquier otro medio que impida el paso del ganado ${ }^{49}$.

Si bien el primer párrafo del artículo 400 del Código civil -«ningún copropietario estará obligado a permanecer en la comunidad»- es aplicable a los postulados de la comunidad de pastos del artículo 600, sin embargo el artículo 400 en lo referente a que «cada uno de ellos podrá pedir en cualquier tiempo que se divida la cosa común», no tiene aplicación al supuesto del artículo 602 del Código Civil, ya que mientras aquél contempla una situación de copropiedad y trata de la división de la cosa común, en cambio la facultad otorgada por éste no es tanto una posibilidad de división, sino de ejercicio de una facultad de separación de la comunidad de pastos.

Por otra parte, la regla general de separación comunitaria -según la cual el comunero que individualiza su cuota abandona la comunidad, deja de participar en la antigua comunidad por ser un extraño-, no se sigue en el párrafo segundo del artículo Go2 que establece la conservación, por el propietario que cercare su finca, de su derecho a la comunidad de pastos en las otras fincas no cercadas. La razón de mantener el derecho a la comunidad se encuentra en que el propietario cerca una finca, no todas sus fincas, lo que significa que no se produce una separación de la comunidad de pastos, ya que no es un extraño al participar todavía con alguna finca o fincas en las comunidad de pastos. De lo contrario, la norma al mantener el derecho a la comunidad de pastos ampararía un enriquecimiento injusto del propietario que desligándose de las obligaciones que la comunidad de pastos comporta, conserva su mismo derecho de aprovechamiento anterior y a costa de los que no proceden al cerramiento. No obstante, se ha entendido desde otra perspectiva que la norma al dejar participar a quien abandonó la comunidad de pastos, en realidad está constituyendo una servidumbre sobre la finca no cercada a favor de quien cerró la suya ${ }^{50}$. supuestos:

El artículo 603 de nuestro Código civil resulta inaplicable en los siguientes

- En primer lugar, a la comunidad de pastos en terrenos públicos del artículo 6oI del propio Código Civil.

- En segundo lugar, cuando en el aprovechamiento comunitario concurra ganado de los propietarios de las fincas con ganados de personas no propietarios, supuesto en el que existe una comunidad de pastos entre los primeros y una servidumbre de pastos respectos de los segundos, al estar gravadas las fincas de los propietarios con el

${ }^{48}$ Cuadrado Iglesias, M., Artículo 6oo, Comentario del Código Civil, Tomo I, Ministerio de Justicia, Madrid, I993, p.I523, «Por esto no justifica de ningún modo la palabra utilizada por el artículo 6o2, que sólo podrá explicarse entendiendo a la comunidad de pastos como una servidumbre recíproca, lo que involucra un evidente confusionismo. Debe suprimirse el vocablo demás que antepone a la palabra servidumbre el referido párrafo que comento».

${ }^{49}$ En este sentido el artículo 58, regla $2^{\text {a }}$ del Reglamento de Pastos, Hierbas y Rastrojeras de 6 de junio de 1969 .

${ }^{50}$ Cuadrado Iglesias, M., Artículo 600, Comentario del Código Civil, Tomo I, Ministerio de Justicia, Madrid, I993, p. I525. 
aprovechamiento de los no propietarios mediante la servidumbre. De permitirse que cualquier propietario pudiera hacer uso del cerramiento para «salir» de la comunidad, existiendo una servidumbre consistente en la carga del aprovechamiento de los no propietarios, se intensificaría la carga de los propietarios que no cerraran sus fincas, haciendo aún más gravosa la servidumbre que soportan.

En suma, ha de entenderse que la posibilidad de salir de una comunidad de pastos en esta situación pasa por lo dispuesto en el artículo 603, a través de la redención.

- En tercer y último lugar, el artículo 602 no es aplicable a las comunidades de pastos anteriores al Código Civil, al amparo de la disposición transitoria primera del Código Civil, salvo que exista un título por el que se constituyó que establezca la posibilidad de que el cerramiento pudiera significar la liberación de la comunidad.

4. Artículo 603.

El precepto regula la redención unilateral de servidumbre de pastos, cuya iniciativa corresponde únicamente al dueño de los terrenos gravados ${ }^{5 \mathrm{II}}$. También puede tener lugar la redención de la servidumbre de pastos en otros supuestos que con carácter general establece el artículo 546-6 del Código civil.

Ahora bien, la redención del artículo 603, a diferencia de la redención de servidumbre en general, es facultativa para el dueño de las fincas gravadas y forzosa para el titular de la servidumbre.

Si bien el precepto alude a la redención de la servidumbre de pastos, se hará extensiva su aplicación a otros gravámenes similares como son los barbechos ${ }^{52}$.

Si la comunidad de aprovechamiento de pastos tiene como causa legitimadora una servidumbre que se ejercita por una pluralidad de beneficiarios, una vez se extinga esa servidumbre por redención, desaparecerá con ella el aprovechamiento comunitario que traía causa en la servidumbre.

El artículo 603 resulta aplicable a las servidumbres constituidas con anterioridad al Código Civil ${ }^{53}$-en base a la disposición Transitoria $\mathrm{I}^{\mathrm{a}}$ del Código Civil-, ya que como es el caso el derecho a redimir aparece declarado por primera vez en el Código, y por tanto «tendrá efecto, desde luego, aunque el hecho que lo origine se verificara bajo la legislación anterior, siempre que no perjudique a otro derecho adquirido, de igual origen». Por el contrario, no es aplicable el artículo 603 en caso de que el derecho de servidumbre establecido antes del Código Civil como irredimible, resulte perjudicado por el derecho de redención que el Código Civil establece.

Por otra parte, a las servidumbres de pastos constituidas con carácter perpetuo,

\footnotetext{
${ }^{51}$ Supuesto no previsto en el artículo 546.6 del Código civil que trata con carácter general de la redención de servidumbres.

${ }^{52}$ Cuadrado Iglesias, M., Artículo 600, Comentario del Código Civil, Tomo I, Ministerio de Justicia, Madrid, I993, p.1526.

${ }^{53}$ Sentencias del Tribunal Supremo de 20 de octubre de i955 y 28 de febrero de 1977.
} 
resulta de aplicación el artículo 603, salvo que a la perpetuidad se añada la expresa abdicación de la facultad de redimir, lo que excluye la redención. Por el contrario no es aplicable el precepto aludido en las servidumbres de pastos establecidas sobre montes públicos -art. 604, a sensu contrario ${ }^{54}$.

Para fijar el valor de la servidumbre que se redime, habrá que estar, primero a lo convenido entre las partes -referido a la cuantía que ha de entregarse por el dueño gravado por la servidumbre al titular o titulares de ésta- y a falta de acuerdo sobre el importe, se estima sobre la base del $4 \%$ del valor anual de pastos corresponde al valor de la servidumbre.

\section{La legislación especial sobre aprovechamiento de pastos.}

I. Legislación estatal especial en materia de pastos.

De 7 de octubre de 1938 data una Ley de la Jefatura del Estado «sobre aprovechamiento de pastos y rastrojeras» (BOE del I2 de octubre de I938). En su escaso preámbulo se puede leer que «las perturbaciones que el actual régimen de aprovechamiento de hierbas y rastrojeras producen en los términos municipales de explotación agrícola parcelada, impone la necesidad de una ordenación que respetando normas consuetudinarias basadas en características comarcales, coordine los intereses agrícolas y ganaderos atendiendo al mayor rendimiento, de acuerdo con el interés nacional.»

Además de que el régimen de explotación agrícola parcelada existente en muchos municipios españoles producía perturbaciones en orden al aprovechamiento ${ }^{55}$ de hierbas, pastos y rastrojeras, existía la circunstancia de ser muy grande le numero de ganaderos que carecían de pastos propios para las necesidades de sus ganados, mientras que había propietarios de fincas rústicas, incluso destinadas a pastos, que no poseían ganado alguno, que aproveche aquellos. Todo ello, obligó al legislador a dictar la Ley de 7 de octubre de I938, disposición ha de calificarse de concisa, al contar sólo con cuatro artículos, en los que se enuncia unos pocos principios generales. Al desarrollarse por reglamentos, se suscita un problema de Derecho Civil latente en el fondo de esta reglamentación: su posible compatibilidad con normas de Derecho Civil, en parte determinada porque la Ley de 7 de octubre de 1938 suscita dudas en relación con el alcance que pueda tener respecto a las

\footnotetext{
${ }^{54}$ Sentencia del Tribunal Supremo de I9 de septiembre de I949.

${ }^{55}$ En cuanto a la naturaleza jurídica de estos aprovechamientos de pastos, hierbas y rastrojeras, pudiera considerarse como una limitación del dominio por la que se impone al propietario un aprovechamiento de sus pastos, hierbas o rastrojeras a favor de terceros mediante una intervención administrativa amparada en la legislación pastueña. Sabido es que nuestro Código Civil admite la existencia de limitaciones del dominio en la propia definición del artículo 348. El aprovechamiento de pastos, hierbas y rastrojeras, constituirían así, limitaciones impuestas por la Ley a determinados predios que se encuentran en determinadas condiciones, señalando, de paso, las condiciones normales del dominio. Se trata de una limitación legal del dominio en base a la convivencia social que exige la subordinación de los intereses privados - propietarios particulares- a lo intereses generales y colectivos, Cfr. Castan Tobeñas, J., Derecho Civil Español, Común y Foral, Tomo 2º Reus, S.A. , Madrid, I992, p. 238 y ss. Contrariamente, NIETO, A., Ordenación de Pastos, Hierbas y Rastrojeras, Tomo I, Junta Provincial de Fomento Pecuario de Valladolid, I959, pp. 278 y ss. , considera que se trata de una expropiación atípica del artículo 2 del Decreto de 26 de abril de 1957, por el que se aprueba el Reglamento de Expropiación Forzosa.
} 
disposiciones del Código Civil, particularmente por la confusa redacción de su preámbulo y del artículo primero de la Ley.

El legislador, en lugar de aprobar un texto legal riguroso, se limitó a extender progresivamente la intervención administrativa en el aprovechamiento de las pastos, mediante el correspondiente desarrollo reglamentario. Así aparecieron sucesivamente los siguientes textos reglamentarios: Orden Ministerial de 30 de enero de I939, Orden de 30 de julio de I94I que desarrolló complementariamente la Ley de Pastos, Orden de I3 de abril de I942, sobre existencia de mancomunidades de Pastos, Orden de 30 de junio de I952 que suprime el respigueo obligatorio, Decreto de 16 de enero de 1953 sobre porcentaje que debe dedicarse a pastizal en las fincas de secano, Decreto de 8 de enero de I954, por el que se aprueba el Reglamento de Pastos, Hierbas y Rastrojeras ${ }^{56}$. Este Reglamento recogió las costumbres tradicionales y sirvió para atender las necesidades económicas en orden al adecuado y más completo aprovechamiento de los pastos, hierbas y rastrojeras. No obstante ello, se estimó aconsejable revisarlo para dar cabida a situaciones surgidas con posterioridad a su publicación, introduciendo las modificaciones aconsejables. En su virtud, se aprueba el Decreto I256/1969, de 6 de junio, por el que aprueba el nuevo Reglamento de Pastos, Hierbas y Rastrojeras, que constituye Derecho estatal supletorio del Derecho de las Comunidades Autónomas, siguiendo lo establecido en el artículo I49.3 de la Constitución Española de 1978. Con ello quiero indicar que el Reglamento estatal de i969 esta llamado a llenar -con las correspondientes adecuaciones establecidas, en su caso, por las Leyes de pastos autonómicas que se vayan aprobando- las lagunas provocadas por la falta de Derecho autonómico en el ámbito de las competencias autonómicas sobre pastos. La carencia de regulación se da en extremos que pueden ser regulados por el Derecho Autonómico, al tener las Comunidades Autónomas competencia para ello, si bien la disponibilidad de la materia por el Ordenamiento suplido ha de aplicarse con las correspondientes adecuaciones en su caso establecidas en la propia ley pastueña de cada Comunidad Autónoma.

2. Legislación autonómica especial sobre aprovechamiento de pastos, hierbas y rastrojeras.

Aparte de la Comunidad Autónoma de Castilla-La Mancha, cuya la Ley 7/2000, de 23 de noviembre de 2000 , de ordenación del aprovechamiento de pastos, hierbas y rastrojeras, analizaremos más adelante, varias han sido las Comunidades Autónomas que han aprobado textos con rango de Ley formal que alude al aprovechamiento de los pastos, hierbas y rastrojeras.

En primer lugar, la Comunidad Autónoma de Cantabria cuenta con la Ley de 26 de marzo de 1990 (Boletín Oficial de Cantabria de 9 de abril de 1990 y Boletín Oficial del Estado de i8 de enero de I99I) que consta de tres títulos. El primero de ellos, se ocupa del ámbito de aplicación considerando zonas de pastoreo en régimen común aquellas áreas de propiedad de entidades locales o agrupaciones de ellas, bien sean montes de utilidad pública o no, en las cuales estacionalmente y de acuerdo con el derecho consuetudinario, se vienen aprovechando los pastos a diente por el ganado (artículo I). Además, se consideran «zonas pastables aquellas que se vienen aprovechando de modo tradicional y que resulten, en su caso de acuerdo con la preceptiva delimitación practicada de los servicios de la Consejería de Ganadería, Agricultura y Pesca de la Diputación Regional, de conformidad con las vigentes Leyes de Montes, de

${ }^{56}$ Vide sobre el mismo a NIETO, A., Ordenación de Pastos, hierbas y rastrojeras, Tomo I y especialmente el Tomo II, Junta Provincial de Fomento Pecuario de Valladolid, I959. 
Protección y Fomento de las Especies forestales Autóctonas y Bases de Régimen local» (artículo 2). Asimismo, y de acuerdo con las costumbres, se consideran también las zonas comprendidas en las franjas denominadas como de «alcance de pastos» que, aunque fuera de la propiedad, «se hayan venido otorgando entre entidades vecinas, o cualquiera otros derechos reales que graven las propiedades, con determinación de su contenido, extensión, beneficiarios, origen y título en virtud del cual fueron establecidos» (artículo 3).

El Título II, se ocupa de los aprovechamientos y mejoras de pastos: los primeros se realizarán dentro de los límites que permitan los intereses de conservación incluidos en los Planes técnicos de Ordenación de Pastos, redactados por los Servicios de la Consejería de Ganadería, Agricultura y Pesca de la Diputación Regional de Cantabria . En cuanto a las mejoras, obras, etc., serán supervisadas por la Consejería de Ganadería, Agricultura y Pesca a través de sus Servicios competentes (artículos 5 y ss.). El Título III, trata de las infracciones y su sanción. Por último esta Ley cuenta con una disposición adicional -facultando al Consejo de Gobierno de la Diputación Regional de Cantabria para que mediante Decreto dictado a propuesta del Consejero de Ganadería, Agricultura y Pesca, para actualizar las cantidades límites señaladas para las sanciones dispuestas en el artículo 22 de la Ley- y dos Disposición finales. La primera autoriza al Consejo de Gobierno de la Diputación Regional de Cantabria para dictar las disposiciones necesarias, al objeto de desarrollar la Ley, la segunda fija la entrada en vigor al día siguiente de su publicación en el Boletín Oficial de Cantabria, el to de abril de I990.

En segundo lugar, en la Comunidad Autónoma de Castilla y León, la Ley i/1999, de 4 de febrero, de Ordenación de los recursos agropecuarios locales y de la tasa por aprovechamiento de los pastos, hierbas y rastrojeras (Boletín Oficial de Castilla y León $\mathbf{n}^{\circ} \mathbf{2 9}$ de I2 de febrero de I999) regula «la problemática vinculada a los negocios agrarios locales de interés particular o colectivo, como son los pastos y rastrojeras, el patrimonio agrario común u otros derechos vinculados o que pudieran vincularse al conjunto de los agricultores y ganaderos y que, por su naturaleza, precisan de una gestión en forma colectiva».

Dicha regulación se basa en las Juntas Agropecuarias como figura asociativa con personalidad jurídica propia en la que habrá de recaer la responsabilidad de la gestión de aquellos negocios, siempre y cuando se cumpla con lo establecido en el Título I de la Ley (artículo I y ss.). En el Título II se regulan los recursos pastables, de las Ordenanzas de Pastos, el aprovechamiento de pastos, sus formas de aprovechamiento y adjudicación «posibilitando además el sistema tradicional de adjudicación directa (a los titulares de explotaciones pecuarias de la localidad sobre las bases económicas de las propuestas de tasación), de la adjudicación por subasta pública, y el convenio directo (entre los titulares de los recursos correspondientes de las explotaciones agrarias y sus homólogos de las explotaciones ganaderas), sin intervención inicial de la Administración en el pacto, pero con más exigencias previas sobre los requisitos y condiciones del Convenio y siempre en la consideración de que en principio tienen prioridad en los aprovechamientos los ganaderos del ámbito local de que se trate». En el Título III se regula el régimen económico y administrativo de los aprovechamientos (Del precio de los pastos y sus gravámenes) y entidades gestoras, así como un régimen sancionador (disposiciones generales, procedimiento sancionador, medidas cautelares, infracciones y sanciones, prescripción). Concluye la Ley con tres disposiciones adicionales, dos transitorias, una derogatoria y dos finales . Incumpliendo la propia disposición final primera que establecía un plazo de seis meses desde la entrada en vigor de la Ley para la aprobación del Reglamento que la desarrollara, la Junta de Castilla y León, en su reunión del día 9 de diciembre de I999, aprueba el Decreto 307/i999, de 9 de diciembre por el que se aprueba el Reglamento General de Ordenación de los recursos agropecuarios locales (Boletín Oficial de Castilla y León nº 239 
de I4 de diciembre de I999), disponiendo su entrada en vigor el día I de enero del año 2000.

En tercer lugar, la Comunidad de Madrid, aprueba la Ley I7/1999, de 29 de abril, sobre aprovechamiento de pastos y rastrojeras para la protección de la ganadería extensiva (Boletín Oficial de la Comunidad de Madrid del lunes I7 de mayo de I999, Boletín Oficial del Estado de $\mathbf{1 6}$ de agosto de 1999). Esta Ley se «limita a establecer las Juntas Locales y las Juntas Provinciales de Fomento Pecuario, atribuyendo a las primeras la competencia para elaborar las Ordenanzas municipales que deben regir el aprovechamiento de los pastos y delimitar y concretar los núcleos parcelarios objeto de los aprovechamientos independientes y otras superficies como los montes, cuyos aprovechamientos son gestionados de conformidad con su legislación específica». Esta nueva regulación legal de pastos y rastrojeras, de 22 artículos, parte de la experiencia de la aplicación del Decreto I256/1969, de 6 de junio y respetando las costumbres inmemoriales que dieron lugar a esta institución. Así, según el preámbulo de la Ley, «se mantiene el hecho mismo de la adjudicación de pastos(artículos 8 y ss.), basada en el mejor aprovechamiento de los recursos naturales (artículo II), que sin perjudicar a la agricultura sirve para el mantenimiento de la ganadería tradicional: la extensiva (artículo 2), a la que ahora se reconoce su efecto benéfico en el medio ambiente». Mantiene la adjudicación a través de la Cámara Agraria de la Comunidad de Madrid, como la mejor garantía de respeto a los intereses colectivos. También se respeta la clasificación de superficies sujetas a la regulación (artículo 4), superficies excluidas (artículo 5) y la posibilidad de segregar fincas o agrupar fincas (artículo 6 y 7 ).

Reconoce la Ley la necesidad de adaptar determinados procedimientos, así como la adjudicación a través de una instancia con ámbito de toda la Comunidad de Madrid, para hacer posible una distribución transparente, pública y en las mismas condiciones en todo su territorio. Precisamente la transparencia en la distribución de los pastos es el objetivo principal que se persigue a la hora de fijar las clasificaciones de las superficies -artículo 2: prados, pastizales, hierbas y rastrojos; propios, ajenos o comunales-, el establecimiento de cargas ganaderas por superficie -Disposición Adicional Segunda- y el establecimiento del orden de preferencia en la adjudicación (artículo 9: los primeros a adjudicar serán los pastos comunales, después se reparte el resto de superficies). En cuanto a los precios -artículo I2-, una vez establecido el precio de unidad ganadera mayor, las equivalencias y las cargas por superficie, convierte el establecimiento del precio en una simple operación matemática que se conocerá con mucha antelación al inicio del año ganadero.

Por otra parte, la Ley respeta la Libertad de los agricultores y ganaderos para pactar privadamente sobre los aprovechamientos pecuarios y la autonomía de estos colectivos en el ámbito municipal, que con ciertas condiciones podrán establecer sus propias Ordenanzas.

Por último la Ley contempla la regulación de las infracciones -faltas administrativas, que se clasifican en leves, graves y muy graves-, fijando quienes son sus responsables, el procedimiento para sancionar. Las sancionándolas son amonestación, multa pérdida del derecho de pastos, así como la prescripción y caducidad de las mismas (artículos i8 a 22 ).

La Ley pastueña madrileña, cuenta con dos disposiciones adicionales: la primera para dejar claro que el Decreto I259/1969, de 6 de junio, por el que se aprueba el Reglamento de Pastos, Hierbas y Rastrojeras, es decir, se aplicará supletoriamente, como Derecho estatal supletorio, en lo no previsto en la presente Ley, recordatorio innecesario porque así lo disponerlo el artículo I48.3 de nuestra Constitución. La segunda, establece las cargas ganaderas máximas por tipo de superficie. La Ley tiene tres disposiciones transitorias, una derogatoria y tres finales. La primera disposición final, establece el plazo máximo de seis meses, para que el Gobierno de la Comunidad de Madrid, elabore el reglamento ejecutivo de 
la presente Ley. En ejecución de este mandato, el Gobierno de la Comunidad de Madrid, en su reunión de fecha 29 de agosto de 2003 , aprueba el Decreto I96/2003, de 29 de agosto, por el que se aprueba el Reglamento ejecutivo de la Ley (Boletín Oficial de la Comunidad de Madrid del martes 16 de septiembre de 2003), que entro en vigor el día siguiente de su publicación, el I7 de septiembre de 2003 .

En cuarto lugar, la Comunidad Autónoma de Aragón, aprobó la Ley 15/2002, de 27 de junio, por la que se deja libre de ordenación el aprovechamiento de los pastos en la Comunidad Autónoma de Aragón (Boletín Oficial de Aragón, $\mathbf{n}^{\circ}$ 79, de 8 de julio de 2002, Boletín Oficial del Estado de 3I de julio de 2002). Este texto legal, cuenta con un artículo único rubricado «Libertad de ordenación»: «Por la presente Ley, queda libre de ordenación el aprovechamiento de los pastos, hierbas y rastrojeras en la Comunidad Autónoma de Aragón». Tiene dos disposiciones transitorias . La primera referida a la «aplicación del sistema de ordenación de pastos» establece que: «el sistema de ordenación de pastos existente a la entrada en vigor de la presente Ley se aplicará hasta la conclusión de la correspondiente campaña de aprovechamiento de pastos».

En la disposición transitoria segunda se prevé la «inaplicación temporal de la libertad de ordenación»: Los Ayuntamientos de los municipios en cuyo término municipal, a la entrada en vigor de esta Ley, se aplique el sistema de ordenación de pastos previsto en la Ley de 7 de octubre de I938, sobre aprovechamiento de pastos y rastrojeras y en su reglamento, dispusieron de un plazo de dos meses desde la entrada en vigor de esta Ley (29 de julio de 2002 hasta el 29 de septiembre del mismo año ), para solicitar a la Administración Autonómica que durante las dos campañas de aprovechamientos de pastos que se iniciaron tras esa fecha, continúe aplicándose en su término municipal el señalado sistema de ordenación, formulándose tal solicitud por acuerdo del Ayuntamiento, una vez consultados los órganos paritarios correspondientes en los que estén representados los agricultores y ganaderos afectados.

La Ley concluye con una Disposición derogatoria y Dos Disposiciones finales. La primera Disposición final, es una habilitación reglamentaria al Consejero responsable en materia de agricultura para dictar cuantas disposiciones sean necesarias para el desarrollo de esta Ley. La segunda, fija la fecha de entrada en vigor de la Ley a los veinte días de su publicación en el Boletín Oficial de Aragón- 29 de julio de 2002-.

La razón fundamental por la cual se deja libre de ordenación el aprovechamiento de los pastos, hierbas y rastrojeras en la Comunidad Autónoma de Aragón, queda muy claramente señalada en el Preámbulo de este texto legal. En el apartado IV se señala que: «el sistema de ayudas establecido en el contexto de la PAC hace prácticamente incompatible una adecuada gestión de las ayudas con la existencia de un sistema general de ordenación de pastos ajeno al que puedan determinar libremente las partes haciéndolo a la luz de las circunstancias específicas del caso». Pero junto a la incidencia del sistema de ayudas diseñado por la PAC, deben añadirse otras circunstancias de carácter estructural que también afectan a la aplicación del sistema de ordenación de pastos: así la extensión de las transformaciones en regadío y la ejecución de procedimientos de concentración parcelaria, circunstancias estas que dan lugar a acuerdos específicos bilaterales entre agricultores y ganaderos. Por todo ello, se concluye en el apartado V del Preámbulo que «hoy existe un escenario en el que resulta indeseable acudir a un sistema de ordenación de pastos intervencionista y generalista -sobre todo porque causas económicas, estructurales, poblacionales y de gestión administrativa conducen a la conclusión de que el mejor modo de aprovechar los pastos, haciéndolo compatible con las circunstancias hoy existentes, es aquel que deje libre de ordenación el mercado, siendo los particulares los que convengan el modo de aprovechamiento de los 
mismos a tenor de las consideraciones que en cada caso confluyan-, añadiendo que dejar libre de ordenación de pastos el territorio de la Comunidad Autónoma, hará posible que «se produzca un aprovechamiento de los pastos más racional, ajustado a las prácticas ambientales que las disposiciones vigentes imponen, así como haciendo compatible un satisfactorio aprovechamiento de los recursos pastables con el cumplimiento de las obligaciones derivadas de los sistemas de ayudas agrarias existentes».

Para finalizar el presente apartado, me referiré a la Ley 6/2003, de 4 de marzo, de Ganadería de la Comunidad Valenciana (Diario oficial de la Generalitat Valenciana de 7 de marzo de 2003, Boletín Oficial del Estado del viernes 4 de abril de 2003) en cuyo título V se ocupa del «Aprovechamiento de pastos y rastrojeras».

El artículo 85 de este Texto Legal señala la jerarquía de las fuentes del ordenamiento del aprovechamiento por la ganadería extensiva de los pastos, hierbas y rastrojeras de las superficies agrícolas y forestales situadas en la Comunidad Valenciana: el citado aprovechamiento se realizará en primer lugar de conformidad con lo dispuesto en este texto legal y en su reglamento, en segundo lugar conforme a lasa ordenanzas aprobadas conforme a la Ley y al Reglamento y supletoriamente -como Derecho supletorio estatal-, será de aplicación el Reglamento de Pastos, Hierbas y Rastrojeras aprobado por Decreto I256/ig69, de 6 de junio, o la normativa estatal que lo sustituya, sin perjuicio del carácter básico o de aplicación directa y preferente que pudieran tener sus disposiciones.

La Ley valenciana, quiere respetar los principios inspiradores asentados en la costumbre, y en su regulación recoge la experiencia más reciente en la gestión administrativa del aprovechamiento de los recursos pastables -Decreto i256/1969, de 6 de junio-, pero adecuando el régimen organizativo y competencial a la nueva realidad de las competencias autonómicas y de la supresión en el ámbito de la Comunidad Valenciana, de las Cámaras Agrarias de ámbito municipal. En síntesis, se opta por una delegación de la Generalitat a favor de los Ayuntamientos, que deberán constituir una Comisión Local de Pastos (con la que se comprometen en la gestión los propios agentes, agricultores y ganaderos), que podrá establecer una tasa por la prestación de los servicios de la gestión del régimen de ordenación del aprovechamiento de los pasto, hierbas y rastrojeras. A las mentadas Comisiones se las dota de un régimen de gestión administrativa simplificado.

El Título V, Capítulo I, establece el régimen común de ordenación del aprovechamiento y su extensión, señalando los términos municipales excluidos, los terrenos excluidos y la segregación de fincas (artículos 85 y ss. ). En el Capítulo II, se contempla los órganos municipales competentes, las Comisiones Locales de pastos -sus funciones y funcionamiento-, las Comisiones Territoriales de pastos -sus funciones y funcionamiento-, y el régimen de recursos (artículo 89 y ss.). El Capítulo III, contempla la ordenación de los pastos y normas generales de aprovechamiento, aludiendo al contenido de las ordenanzas, al procedimiento de aprobación de las mismas y su publicidad. Se ocupa además, del alzado de los rastrojos, de la entrada del ganado en los rastrojos, del aprovechamiento en circunstancias especiales y de los daños (artículo 98 y ss.). El Capítulo IV al tratar de la adjudicación de los aprovechamientos, se ocupa de la adjudicación directa y subasta pública. Se fijan los criterios de preferencia en la adjudicación y el régimen de adjudicación (art. I05 y ss.). Por último, el Capítulo V, establece el «Régimen económico», fijación de precios, el cobro y pago del precio, así como la tasa municipal. Por último, indicar la fecha de entrada en vigor del texto legal: el 28 de marzo de 2003 . 
IV. La Ley $7 / 2000$, de 23 de noviembre de 2000 , de ordenación del aprovechamiento de pastos, hierbas y rastrojeras de la comunidad autónoma de Castillla-La Mancha.

La Ley castellano-manchega, en su exposición de motivos, primero justifica la competencia de la propia Comunidad Autónoma para legislar sobre esta materia. Alude al artículo 3I.I.6. del Estatuto de Autonomía que atribuye a la Junta de Comunidades de Castilla-La Mancha, la competencia exclusiva en materia de agricultura y ganadería, de acuerdo con la ordenación general de la economía. Se señala que el artículo 32.2 del Estatuto de Autonomía le atribuye a la Comunidad Autónoma competencia para el «desarrollo legislativo y la ejecución en el marco de la legislación básica del Estado, en materia de pastos». Asimismo, «los artículos 3I.I.28, 32.I y 32.2., de dicho texto legal, atribuyen a la Junta de Comunidades de Castilla-La Mancha competencia exclusiva sobre el procedimiento administrativo derivado de las especialidades de la organización propia, y el desarrollo legislativo y la ejecución de la normativa básica del Estado en materia de régimen local y montes.»

El legislador castellano-manchego, nos recuerda la gran importancia económica del aprovechamiento de los recursos pastables. Así, en la exposición de motivos se señala como este subsector productivo emplea un elevado número de puestos de trabajo directo «contribuyendo de manera decisiva al incremento de la renta agraria» de la región-, así como puestos de trabajo indirectos a través de las actividades económicas de transformación y comercialización de productos alimentarios -vg. carne, leche, queso- .

El legislador parte de la consideración de los pastos y ratrojeras como «un patrimonio agrario común» al que pueden vincularse al conjunto de agricultores y ganaderos, precisando, en consecuencia una gestión en forma colectiva y administrativamente. En lugar de buscar un esquema corporativo, aunque se actualice la participación de los agricultores y ganaderos, hubiese sido preferible, a mi juicio, un régimen de libre contratación en el que los titulares de los aprovechamientos (que a falta de calificaciones jurídico reales típicas, como la servidumbre o la comunidad, y donde no hay un régimen consuetudinario claro y asentado, corresponden al titular de las facultades de goce y disfrute del fundo de que se trate), los cediesen a través de un contrato, percibiendo una contraprestación por la correlativa limitación de las facultades de goce y disfrute del fundo en cuestión. Por el contrario, la Ley 7/2002, se reafirma en la necesidad de una existencia de una regulación, que no deja a la autonomía de la voluntad de los agricultores y ganaderos en cada caso particular, la gestión de los aprovechamientos de los pastos, en función de sus circunstancias concretas. Ahora bien, esa regulación legal de la gestión administrativa de la utilización de los recursos pastables, reconoce que no puede llevarse a cabo por una Ley de I938 y su reglamento de I969, normativa estatal considerada obsoleta y que requiere ser actualizada, entro otras cosas para permitir un adecuado sistema de participación de los agricultores y ganaderos.

La Ley se estructura en cinco títulos. El Título I se ocupa de los Principios Generales y su Capítulo I se refiere al Ámbito de Aplicación.

I. Objeto de la Ley y ámbito de aplicación.

El objeto de la Ley es la ordenación y regulación del aprovechamiento de los pastos, hierbas y rastrojeras, así como del establecimiento y la regulación de composición, funciones 
y régimen de funcionamiento de los órganos competentes en la materia ${ }^{57}$.

Se trata de ordenar uno de los aprovechamientos que admiten las tierras a fin de favorecer la explotación ganadera en régimen extensivo que permite llevar a cabo la alimentación ganadera, utilizando los aprovechamientos a diente de los pastos, hierbas y rastrojeras.

El legislador castellano-manchego para denominar esta Ley ha utilizado una enumeración casuística al plantear la ordenación del aprovechamiento de pastos, hierbas y rastrojeras. Sin embargo, después en su artículo i4 únicamente define los pastos, eso si, tratando de comprender los tres conceptos enumerados. Semejante tratamiento cabe considerarlo como adecuado ya que, si bien estamos en presencia de tres ideas conceptualmente próximas, en realidad son difíciles de distinguir.

Los pastos, son hierbas -vegetal que brota espontáneamente- que puede servir de alimento al ganado, pudiendo ser ese el fin principal de la parcela en la que brota. Algo distinto es la rastrojera. Se trata de lo que queda en un campo cultivado después de la recolección de sus frutos. Se trata de los restos que quedan en el campo después de retirar el cultivo agrícola. Pensemos por ejemplo en las espigas caídas en la tierra después de separadas del tallo ${ }^{58}$.

En suma, la aplicación de la Ley se realiza a toda producción vegetal -por circunstancial o secundaria que sea- que tenga como fin alimentar al ganadoindependientemente del destino del fundo en el que brotan-, y se extiende a superficies sometidas al régimen común de aprovechamiento de pastos, situadas dentro del ámbito geográfico de región Castilla-La Mancha ${ }^{59}$.

Por tanto, resultan objeto de la presente Ley la totalidad de aprovechamientos de pastos, hierbas y rastrojeras que se realicen en el territorio de Castilla-La Mancha, salvo las zonas excluidas donde la ganadería tiene poca importancia al ser fundamentalmente agrícolas -zonas de regadio, huertas, superficies plantadas de viñedo, olivares, frutales o forestales-, los montes catalogados de utilidad pública, excluyéndose también en los territorios donde la actividad pastueña pueda producir en la zona interferencias o molestias en el cultivo agrícola o forestal ${ }^{60}$. Por último, cabe también la exclusión de superficies respecto de la aplicación de la Ley, a través de la exclusión del régimen común de aprovechamientos de pastos por agrupación de fincas colindantes en la forma y con los requisitos establecidos en el artículo 20 del propio texto legal.

${ }^{57}$ Artículo $\mathrm{I}^{\circ}$ de la Ley Castellano-Manchega, 7/2000, de 23-II-2000, de Ordenación del Aprovechamiento de Pastos, Hierbas y Rastrojeras.

${ }^{58}$ NiETO, A. Ordenación de Pastos, Hierbas y Rastrojeras, Tomo II, Junta Provincial de Fomento Pecuario de Valladolid, I959, pp. 30 y 3 I.

${ }^{59}$ Artículo I.2 $^{\circ}$ de la Ley Castellano-Manchega, 7/2000, de 23-II-2000, de Ordenación del Aprovechamiento de Pastos, Hierbas y Rastrojeras.

${ }^{60}$ La exclusión de superficies está prevista en la Sección segunda del Título II, Capítulo II, artículo I9 de la Ley de pastos de Castilla-La Mancha. 
2. La jerarquía de fuentes.

El artículo segundo de la Ley enumera las fuentes reguladores de esta materia. Los aprovechamientos de pastos «se regirán por lo dispuesto en esta Ley, por las Ordenanzas de pastos y por las normas consuetudinarias que deberán ser recogidas en las referidas ordenanzas».

El precepto encaja en la teoría general de la jerarquía de fuentes expuestas en el artículo primero del Código civil «I. Las fuentes del ordenamiento jurídico español son la ley, la costumbre y los principios generales del derecho».

Aparte de la Ley en sentido estricto, y de otras normas escritas como los reglamentos, la costumbre tiene una peculiar importancia como fuente de derecho en la regulación de los pastos, hierbas y rastrojeras, normando relaciones jurídicas del medio rural que en ocasiones no han sido resueltas o ni tan siquiera previstas por el legislador.

El artículo alude a las «normas consuetudinarias» que deberán ser recogidas en las ordenanzas. El precepto plantea el problema de la validez de las normas consuetudinarias que no se recojan en las ordenanzas de pastos. Pudiera entenderse que lo afirmado en el precepto es la imposibilidad de aplicación de normas consuetudinarias cuando no estén incluidas en las ordenanzas. Sin embargo, no encaja ese planteamiento con lo dispuesto en el artículo primero, apartado tercero de nuestro Código civil: «La costumbre sólo regirá en defecto de ley aplicable, siempre que no sea contraria a la moral o al orden público y que resulte probada». En base a este precepto, si algún particular alega alguna costumbre fuera de las ordenanzas de pastos, no por ello ha de desestimarse, salvo que no resulte probada por otros medios que no suele ser tan sencillos como la Ordenanza. En suma, la diferencia, a efectos legales, entre las costumbres recogidas y las no recogidas, se encuentra en que mientras las primeras, por estar recogidas en las ordenanzas de pastos son fuentes directas de derecho, las no recogidas lo son indirectas ${ }^{6 \mathrm{I}}$.

Por todo ello, la expresión legal requiriendo que las normas consuetudinarias estén recogidas en las ordenanzas pastueñas, ha de entenderse en el sentido de tratar de facilitar la prueba de la costumbre, ya que otra interpretación conduciría a dejar al particular desamparado al establecerse una rigidez que no prevé el propio Código Civil, que admite respecto de la costumbre, todos los medios de prueba.

Por último, haciendo referencia a los Principios Generales del Derecho como fuente del Ordenamiento Jurídico Español, la propia exposición de motivos de la Ley 7/2000, alude a algunos móviles de la redacción legal, pudiendo considerarse principios generales del Derecho que han servido para informar y en cuya contemplación se ha redactado el correspondiente texto legal. Dos son, al menos, los principios previstos. El primero consiste en hacer compatible la protección del medio natural con la explotación rentable de espacios y razas ganaderas mantenidas en régimen extensivo. El segundo, viene referido a la coordinación de los intereses agrícolas y ganaderos, al configurarse la ley como instrumento al servicio de los agricultores y ganaderos, verdaderos artífices de la regulación de este sector tan importante.

Estos principios seguidos por los redactores de la Ley, se tendrán presentes, en todo caso, al realizar la labor interpretativa. Por eso, en caso de duda, a ellos debemos atenernos,

\footnotetext{
${ }^{6 r}$ Nieto, A., Ordenación de Pastos, Hierbas y Rastrojeras, Tomo II, Junta Provincial de Fomento Pecuario de Valladolid, I959, , pp. 46 y 47.
} 
sin olvidar, que tales principios son fuente de derecho cuando no exista Ley ni costumbre directamente aplicable.

3. La organización administrativa.

En el artículo tercero se ocupa la Ley de la organización administrativa, estableciendo cuatro órganos competentes en materia de aprovechamiento de pastos, hierbas y rastrojeras: las Comisiones locales de pastos, las Comisiones provinciales de pastos, las Delegaciones provinciales competentes en materia de agricultura y ganadería y por último, la Consejería competente en materia de agricultura y ganadería.

\section{I. Comisión local de pastos.}

Para que los agricultores y ganaderos sean los verdaderos artífices de la regulación del aprovechamiento de pastos, hierbas y rastrojeras, la Ley crea la Comisión Local de pastos, que deberá constituirse en todos los municipios de Castilla-La Mancha, estando constituida por representantes de los propietarios de tierras y de los ganaderos, y serán ellos los que decidan cómo quieren que se ordene en su municipio el aprovechamiento de los pastos.

La Comisión Local de pastos se constituirá en todos los municipios de Castilla-La Mancha. Ejercerán sus funciones sobre el respectivo término municipal, durante su mandato de cuatro años asignándole la Ley competencias en materia de aprovechamientos de pastos, hierbas y rastrojeras.

La Comisión local de pastos está compuesta por un presidente, seis vocales y un secretario.

La preside, el alcalde del municipio -o concejal, en quien delegue-, que tendrá voz pero no voto.

Tres vocales en representación de los propietarios de tierras del término municipal sujetas al régimen de ordenación de pastos. No basta con la condición de propietario, ya que el apartado quinto del artículo cuarto, establece que para poder ser elegido vocal en representación de los propietarios se requiere que las «rentas que perciban procedan exclusiva o mayoritariamente del sector respectivo al que representa». No está pensando el legislador en el en el dueño de la tierra, sino en el propietario cultivador, esto es en los agricultores propietarios de la tierra que obtienen más del cincuenta por ciento de su renta de la actividad agraria. En este punto la Ley va más allá del requisito de renta exigido por la Ley 19/1995, de Modernización de Explotaciones Agrarias, para ser, a los efectos de ese texto legal, agricultor profesional y parece indicar que deben ser agricultores a título principal, definidos en relación a la procedencia de sus rentas y el tiempo dedicado a actividades agrarias ${ }^{62}$.

En este requisito de ser agricultor propietario, para ser vocal en representación de los propietarios de tierras, abunda el texto legal cuando establece la forma de su nombramiento artículo 4.3-. Serán nombrados por el pleno del Ayuntamiento, a propuesta de las Organizaciones profesionales agrarias más representativas en la provincia o en la región-,

\footnotetext{
${ }^{62}$ Artículo 2.6 de la Ley 19/1995, de 4 de julio, de modernización de las explotaciones agrarias.
} 
pero teniendo presente la representación de esas organizaciones en la propia localidad. El legislador llega a plantear el supuesto de que no existieren representantes de las organizaciones profesionales agrarias en el respectivo término municipal o bien existiendo, no fuesen propuestos por las organizaciones profesionales. En este caso la vacante o vacantes serán cubiertas por designación del Pleno entre los vecinos que ostenten la condición de propietario de tierras pero, cuyas rentas procedan exclusivamente o mayoritariamente de la agricultura, por ser al sector agrícola - no al pecuario- al que representa. Si no hubiese vecinos que reuniesen tal condición, el puesto o puestos vacantes serán cubiertos, previa designación del Pleno del Ayuntamiento, por uno o más Concejales del Ayuntamiento.

Desafortunado ha de considerarse el párrafo segundo del apartado cuarto del artículo cuarto del texto legal, al establecer que «la condición de propietario, a estos efectos, se acreditará mediante certificación de la Comisión Local de Pastos, de ser propietario de tierras sujetas al régimen de ordenación de pastos del término municipal». Es claro que la condición de propietario no queda acreditada así, sino como establece el propio precepto «in fine» cuando establece: «La propiedad de la tierra se acreditará mediante la correspondiente escritura pública o por cualquier otro documento público o privado válido en derecho». En suma, lo que acredita la certificación de la Comisión local de pastos es la sujeción de las tierras al régimen de ordenación de pastos del término municipal.

La Ley, al aludir a la representación de los propietarios de tierras, deja al margen y sin representación a aquellos titulares de explotaciones agrícolas en concepto de arrendatario, aparcero, usufructuario que ejerzan la actividad agrícola y que se encuentran dados de alta en el régimen especial agrario de la Seguridad Social por cuenta propia o en el Régimen especial de trabajadores Autónomos.

Por el contrario, pueden formar parte de la Comisión local de pastos, los representantes de las personas jurídicas que conforme a sus estatutos, tenga por exclusivo objeto la actividad agrícola y la ejerzan efectivamente.

Tres vocales en representación de los ganaderos con explotación en el término o bien con explotación pecuaria en otro término municipal, con pastos adjudicados en el municipio donde se constituye la Comisión Local de Pastos. Estos ganaderos para poder ser elegidos tienen que: contar con cartilla ganadera actualizada, llevar un libro de registro de explotación actualizado y estar al corriente de pagos por los pastos adjudicados ${ }^{63}$. Además, no basta con la condición de ganadero, ya que el apartado quinto del artículo cuarto, establece que para poder ser elegido vocal en representación de los ganaderos se requiere que las «rentas que perciban procedan exclusiva o mayoritariamente del sector respectivo al que representa», esto es, que obtiene más del cincuenta por ciento de su renta de la actividad pecuaria.

Puede ser vocal en representación de los ganaderos, las personas físicas titulares de explotaciones ganaderas - profesionales del sector que ejercen la actividad pecuaria, dados de alta en dado de alta en el Régimen Especial agrario de la Seguridad Social por cuenta propia o en Régimen Especial de Trabajadores Autónomos-, o los representantes de cualquier persona jurídica -que conforme a sus estatutos, tenga por exclusivo objeto la actividad ganadera y la ejerza efectivamente-.

En cuanto a la forma de su nombramiento, serán nombrados por el pleno del Ayuntamiento, a propuesta de las Organizaciones profesionales agrarias más representativas

63 Artículo 4.2.c. de la Ley Castellano-Manchega, 7/2000, de 23-II-2000, de Ordenación del Aprovechamiento de Pastos, Hierbas y Rastrojeras. 
en la provincia o en la región, pero teniendo presente la representación de esas organizaciones en la propia localidad ${ }^{64}$. El legislador plantea el supuesto de que no existiesen representantes de las organizaciones profesionales agrarias en el respectivo término municipal o bien existiendo, no fuesen propuestos por las organizaciones profesionales. En este caso la vacante o vacantes serán cubiertas por designación del Pleno entre los vecinos que ostenten la condición de ganadero pero cuyas rentas procedan exclusivamente o mayoritariamente de la actividad pecuaria, por ser al sector ganadero al que representa. Si no hubiese vecinos que reuniesen tal condición, el puesto o puestos vacantes serán cubiertos por designación del Pleno por uno o más Concejales del Ayuntamiento. Quedan así excluidos, en este último supuesto, los ganaderos vecinos de otras localidades por mucho que tengan adjudicados pastos en el municipio en el que se constituye la Comisión Local de Pastos.

Los vocales de la Comisión Local de pastos ${ }^{65}$, lo son en representación de los propietarios de tierras del término sujetas a régimen de ordenación de pastos y de los ganaderos con explotación en el término o con pastos adjudicados en el municipio, y no de las organizaciones profesionales agrarias más representativas, las cuales se limitan a realizar la propuesta al Pleno del Ayuntamiento a los efectos de su nombramiento como vocales de la Comisión Local de pastos en representación de propietarios de tierras afectados y ganaderos.

En todo caso, la Ley prohíbe compatibilizar la representación de propietarios de tierras y ganaderos en una misma persona. Si un ganadero es además agricultor propietario de tierras del término municipal sujetas al régimen de ordenación de pastos, únicamente podrá ostentar la representación de un sector, esto es, de aquel del que perciba mayoritariamente sus rentas ${ }^{66}$.

Por último, el secretario, será nombrado por el Presidente, de entre los funcionarios del Ayuntamiento respectivo y al igual que el propio presidente, tendrá voz pero no voto. En muchos municipios pequeños, el secretario de la Comisión Local de pastos, será el propio secretario del Ayuntamiento, al ser el único funcionario capacitado, para tal puesto. Ahora bien, el Secretario del Ayuntamiento es un Funcionario de Habilitación Nacional, al servio exclusivo de la Administración municipal, y no al servicio de otros organismos que nada tienen que ver, en principio, con aquella. Por tanto, si la Ley 7/2000, le asigna determinadas funciones, se le deben retribuir, en forma de gratificaciones extraordinarias, pero no con cargo al erario municipal, puesto que tales funciones no se encuentran entre las que la legislación local le atribuye como secretario del Ayuntamiento respectivo.

Respecto a la competencias que corresponden a las Comisiones locales de pastos, el artículo quinto de la Ley señala las siguientes:

a) Redactar las ordenanzas de pastos, hierbas y rastrojeras de su municipio, proponiendo su aprobación -y en su caso su modificación-, a las Delegaciones Provinciales de la Consejería competente en materia de agricultura y

${ }^{64}$ Artículo cuarto, apartado $3^{\circ}$, de la Ley Castellano-Manchega, 7/2000, de 23-II-2000, de Ordenación del Aprovechamiento de Pastos, Hierbas y Rastrojeras.

${ }^{65}$ Artículo cuarto, apartados tercero y cuarto de la Ley Castellano-Manchega, 7/2000, de 23-II2000, de Ordenación del Aprovechamiento de Pastos, Hierbas y Rastrojeras.

${ }^{66}$ Artículo 4.5 de la Ley Castellano-Manchega, 7/2000, de 23-II-2000, de Ordenación del Aprovechamiento de Pastos, Hierbas y Rastrojeras. 
ganadería $^{67}$.

b) Establecer las delimitaciones de polígonos de pastos. El terreno sometido a ordenación común se encuentra dividido, a efectos de su aprovechamiento, en polígonos ganaderos constituidos por una superficie de terreno, delimitada para fines pastueños.

Además la Comisión Local de pastos, debe formular tres meses antes del comienzo del año ganadero ${ }^{68}$ y dentro de los límites aprobados por la Comisión Provincial de Pastos - precios mínimos y máximos ${ }^{69}-$, la propuesta de tasación, detallando el precio por hectárea y cabeza de ganado que debe regir bien para el disfrute en circunstancias normales de los pastos, hierbas y rastrojeras, o bien para ese disfrute en casos extraordinarios determinados por cosechas deficientes no recolectadas.

c) Confeccionar un Registro Público en el que consten todos los propietarios de tierras sujetos a ordenación, así como los ganaderos adjudicatarios de pastos. Se trata de un Registro oficial cuyo objeto -que no es la inscripción o constitución de los actos y contratos relativos al dominio y demás derechos reales sobre bienes inmuebles-, se limita a relacionar aquellos que han acreditado, mediante cualquier documento válido en derecho, ser propietarios de tierras sujetas al régimen de ordenación de pastos.

d) Dentro de los precios mínimos y máximos establecidos por la Comisión Provincial $^{70}$, le corresponde a la Comisión Local fijar la cuota a satisfacer por cabeza de ganado de las diversas especies en el caso de las piaras -manadas- o rebaños concejiles o dulas. En este último caso, se trata de fijar la cuota a satisfacer por cabeza de ganado de los vecinos de un pueblo que se envían a pastar juntos a un terreno comunal.

e) Fijar, dentro del máximo y mínimo determinado por la Comisiones Provinciales de Pastos $^{71}$, las cargas ganaderas.

f) Adjudicar los aprovechamientos, esto es, todos aquellos productos procedentes de praderas, eriales o productos secundarios de explotaciones agrícolas o forestales que sean susceptibles de servir como alimento de ganado ${ }^{72}$.

${ }^{67}$ Artículo 9.a, de la Ley Castellano-Manchega, 7/2000, de 23-II-2000, de Ordenación del Aprovechamiento de Pastos, Hierbas y Rastrojeras

${ }^{68}$ El año ganadero, se determinará reglamentariamente. El artículo 2 del Reglamento General de Ordenación de los recursos agropecuarios, aprobado por la Junta de Castilla y León por Decreto 307/1999, de 9 de diciembre, establece que el año ganadero es el comprendido entre el i5 de mayo de un año y el I4 de mayo del año siguiente.

${ }^{69}$ Artículo 8, de la Ley Castellano-Manchega, 7/2000, de 23-II-2000, de Ordenación del Aprovechamiento de Pastos, Hierbas y Rastrojeras.

${ }^{70}$ Artículo 8.d de la Ley Castellano-Manchega, 7/2000, de 23-II-2000, de Ordenación del Aprovechamiento de Pastos, Hierbas y Rastrojeras.

${ }^{71}$ Artículo $8 \mathrm{f}$. de la Ley Castellano-Manchega, 7/2000, de 23-II-2000, de Ordenación del Aprovechamiento de Pastos, Hierbas y Rastrojeras.

${ }^{72}$ Vide artículo I4 de la Ley 7/2000 de Castilla-La Mancha, en el que se define que se entiende por 
También tiene encomendada la resolución de las reclamaciones que se hubiesen producido contra dicha adjudicación y cuya revisión o revocación corresponde, en su caso, a las Comisiones Provinciales de Pastos, previa audiencia a los partes afectadas: comisión local, propietarios de tierras o ganaderos ${ }^{73}$.

g) Celebrar las subastas de adjudicación de polígonos de pastos en los supuestos en que procedan según lo previsto en el artículo i5.I.c.

h) Realizar el cobro de los pastos a los ganaderos adjudicatarios y realizar el pago a los propietarios de las tierras sujetas a ordenación. Gestionará el cobro del precio de los pastos a los ganaderos adjudicatarios y realizará igualmente el pago a los propietarios de las tierras sujetas a ordenación. Obsérvese como el pago de los pastos se efectuará a todos los propietarios de tierras sujetas a ordenación excluyese a otros titulares de derechos reales o personales sobre las fincas que no sean propietarios de las tierras : usufructuarios, arrendatarios, apareceros, ${ }^{74}-$, e independientemente de la procedencia de sus rentas, aspecto este último que si es tenido en cuenta por el legislador a los efectos de representación de los propietarios de tierras en la Comisión Local de Pastos.

A estos efectos del cobro de los pastos, la comisión podrá acordar que el cobro de los pastos sea previo a su aprovechamiento.

Por otra parte ante la situación en la cual el propietario de las tierras sea a su vez acreedor y deudor de pastos, en su condición de ganadero adjudicatario, es lógico que se efectúe una liquidación por la diferencia.

Cabe la renuncia del propietario de las tierras al cobro de sus participaciones en el precio de los pastos, que se hará a favor de la Comisión, siempre que esa renuncia se efectúe individualmente y por escrito.

i) La Comisión Local de pastos determinará el porcentaje a detraer de los ingresos, dentro del límite fijado: «podrán detraer hasta un $20 \%$ de los ingresos del valor de adjudicación de aprovechamiento de pastos, para sufragar gastos de funcionamiento de la misma o para las mejoras de los aprovechamientos», como obras de interés general agrario, descansaderos, abrevaderos, caminos, veredas, cañadas, «si se ejerciese esta facultad, se nombrará un Tesorero que junto con otro miembro de la Comisión serán los responsables de estos fondos» ${ }^{75}$.

pastos.

${ }^{73}$ Vide los artículo 8.h y 25 de la Ley 7/2000, de 23-II-2000, de Ordenación del Aprovechamiento de Pastos, Hierbas y Rastrojeras, de Castilla-La Mancha.

${ }^{74}$ Contrasta este criterio con el seguido por el artículo 70 del Reglamento General de Ordenación de los recursos agropecuarios, aprobado por la Junta de Castilla y León por Decreto 307/I999,en cuyo apartado primero establece: «Realizadas las deducciones del precio y, en su caso, la detracción complementaria para mejoras, de acuerdo con los establecido en el artículo anterior, los fondos restantes serán distribuidos por la Junta agropecuaria local entre los titulares de las explotaciones agrícolas, en proporción a sus respectivas superficies y aprovechamientos, dentro de los sesenta días naturales siguientes a la fecha de finalización del aprovechamiento establecida en las Ordenanzas».

75 Artículo 5.3. de la Ley Castellano-Manchega, 7/2000, de 23-II-2000, de Ordenación del 
j) También le corresponde a la Comisión Local proponer la exclusión e inclusión de fincas en el régimen común de ordenación de pastos, cuya aprobación definitiva corresponde al Delegado Provincial de la Consejería ${ }^{76}$.

Por primera vez la Ley pastueña castellano-manchega, en este precepto, hace referencia a las «fincas», ya que el legislador hasta este lugar, toda alusión al suelo rústico, venia dado por la expresión «tierras» del término municipal. La referencia al predio, se hace en el sentido de finca material o «trozo de la superficie terrestre cerrado por una línea poligonal y objeto de propiedad» ${ }^{77}$.

Para proceder a la exclusión e inclusión de fincas ha de tener presente por la Comisión Local las superficies que la Ley menciona expresamente incluidas y excluidas de la ordenación común de aprovechamiento ${ }^{78}$.

k) La Comisión, en relación con los cultivos herbáceos -con naturaleza de hierba-, establecerá el plazo durante el cual, no podrá acceder el ganado a las fincas, una vez levantada la cosecha.

El legislador, en este apartado, al referirse únicamente a los cultivos herbáceos, de una parte, se refiere a como dar a la tierra y a las plantas de hierba las labores necesarias para que fructifiquen; y de otra parte, parece excluir los pastizales, dominados por especies herbáceas que por efecto del clima, se secan o agostan en verano, su densidad es variable y frecuentemente están salpicados de especies leñosas.

1) Le corresponde también, informar a la Comisión Provincial de Pastos de cuantos asuntos estimen de interés para el fomento y mejora de la ganadería, proponiendo las soluciones a adoptar.

m) Remitir a la Delegación Provincial de Agricultura y Medio Ambiente, una vez realizada, copia autenticada del documento acreditativo de la adjudicación.

n) Comunicar a la Comisión Provincial la composición de la Comisión Local.

o) La Comisión Local tendrá cuantas otras competencias que el Reglamento de pastos, hierbas y rastrojeras, aprobado por Decreto I256/1969, de 6 de junio, atribuían a las antiguas Comisiones Mixtas Locales y que no estén atribuidas por esta Ley a otro órgano.

Este apartado es muestra de una deficiente técnica legislativa puesto que se remite en general a un Reglamento estatal, y cuya vigencia futura no depende de la Comunidad Castellano-Manchega, obligando a los operadores jurídicos a

Aprovechamiento de Pastos, Hierbas y Rastrojeras.

${ }^{76}$ Artículo 9.f., de la Ley Castellano-Manchega, 7/2000, de 23-II-2000, de Ordenación del Aprovechamiento de Pastos, Hierbas y Rastrojeras.

${ }^{77}$ Sentencia del Tribunal Supremo de io de diciembre de i960. Sobre el concepto de finca registral vide a GARCíA GARCíA, J.M., La finca como base del sistema inmobiliario, Revista Crítica de Derecho Inmobiliario, $\mathrm{n}^{\circ}$ 625, nov-dic. I994, p. 2442.

${ }^{78}$ Respectivamente en los artículos I8.I y I9, de la Ley Castellano-Manchega, 7/2000, de 23-II2000, de Ordenación del Aprovechamiento de Pastos, Hierbas y Rastrojeras. 
acudir al citado Reglamento para tener una visión completa de las competencias de las Comisiones Locales de Pastos. En buena técnica legislativa deberían señalarse explícitamente por el propio texto legal y a lo sumo remitirse a un posterior desarrollo, en su caso, por el correspondiente reglamento aprobado por la Comunidad Autónoma de Castilla-La Mancha.

Lo mismo cabe decir respecto de lo dispuesto en la disposición adicional tercera, al establecer que «las competencias que el Reglamento de Pastos, Hierbas y rastrojeras, aprobado por Decreto $1256 / 1969$, de 6 de junio, atribuye a las Hermandades Sindicales Locales de Labradores y Agricultores y a las Comisiones Mixtas quedan atribuidas a las Comisiones Locales de Pastos.

p) Informar a la Delegación Provincial sobre agrupación de fincas para su exclusión del régimen común de aprovechamientos ${ }^{79}$.

Ese informe es preceptivo para que los titulares de fincas rústicas colindantes puedan solicitar la autorización de la Delegación Provincial para agrupar sus fincas, excluyéndolas del régimen común de aprovechamiento, dado que :

a) las fincas forman un coto bien delimitado y no obstaculiza los demás aprovechamientos

b) el aprovechamiento de las fincas se efectúa por ganado que posean o adquieran los titulares de las fincas agrupadas.

c) las fincas agrupadas puedan sustentar un número de unidades de ganado mayor que fije la Delegación Provincial.

«Si transcurridos dos meses no se hubiese evacuado el citado informe, se entenderá como silencio positivo» ${ }^{8 \circ}$.

En el apartado segundo del artículo 5, se resuelve la situación creada, referida a una votación, ante un empate entre los miembros de la Comisión, situación que puede no resultar excepcional dado el igual numero de votos de la representación de los propietarios de las tierras y de los ganaderos, máxime cuando ni el presidente ni el secretario cuentan con voto. El papel del presidente en estos casos será fundamental, ya que dada la composición paritaria de la Comisión, le corresponderá, en ausencia de voto, una labor de mediación a fin de acercar posturas para conseguir los acuerdos necesarios en orden a la adjudicación ya aprovechamiento de los pastos.

De persistir ese empate -tras celebrarse sucesivas votaciones-, durante un mes, la Comisión Local elevará el asunto a la Comisión Provincial que dictará una resolución dirimente en el plazo de un mes.

\footnotetext{
${ }^{79}$ Respecto de la agrupación de fincas vide el artículo 20 de la Ley $7 / 2000$, de 23 de noviembre de 2000, de ordenación del aprovechamiento de Pastos, Hierbas y Rastrojeras de Castilla-La Mancha.

${ }^{80}$ Artículo 5. p) de la Ley 7/2000 de 23-II-2000, de Ordenación del Aprovechamiento de Pastos, Hierbas y Rastrojeras de Castilla-La Mancha.
} 


\subsection{Comisiones provinciales de pastos.}

Se trata de órganos colegiados de la Junta de Comunidades de Castilla-La Mancha, integrados en la Consejería de Agricultura y Medio Ambiente.

Al formar parte de la Administración autonómica, sus competencias son ejecutivas y de coordinación en el ámbito de su provincia en las materias relacionadas con esta normativa de pastos, hierbas y rastrojeras. Su mandato dura cuatro años ${ }^{{ }^{\mathrm{I}} \mathrm{I}}$.

En cuanto a su composición, las Comisiones Provinciales estarán integradas por:

q) un presidente, que lo será el Delegado Provincial de la Consejería competente en materia de agricultura y ganadería o persona que le sustituya.

r) Un vicepresidente, nombrado por el presidente, entre uno de los dos funcionarios que forman parte de la Comisión Provincial y pertenecientes a la Delegación Provincial con competencias en materia de agricultura y ganadería. Las funciones del vicepresidente serán únicamente de asesoramiento. En suma, uno de los dos funcionarios pertenecientes a la Delegación Provincial con competencias en materia de agricultura y ganadería y que se integran en la Comisión, será el vicepresidente y el otro un vocal de la misma.

s) Dos representantes de la Cámara Agraria Provincial - uno del sector agrícola y otro del sector ganadero-, a propuesta del Pleno de la misma y nombrados por el Delegado Provincial de Agricultura.

t) Tres vocales en representación de los propietarios de tierras sujetas a ordenación en cualquier término municipal de la provincia. Estos vocales serán nombrados por el Delegado provincial de la Consejería competente en materia de Agricultura, y Ganadería, pero a propuesta de las organizaciones profesionales agrarias, con lo que se indica que la propuesta será de los «propietarios de tierras» que sean profesionales de la agricultura, no siendo suficiente con ser dueño, sin más, de la tierra. Las organizaciones profesionales propondrán a agricultores que se dediquen profesionalmente a la actividad agraria y que sean propietarios de la tierras sujetas a ordenación en cualquier término municipal de la provincia. En suma, no basta con la condición de propietario, si no que se requiere que las «rentas que perciban procedan exclusiva o mayoritariamente del sector respectivo al que representa». No está pensando el legislador en el dueño de la tierra, sino en el propietario cultivador que obtiene más del cincuenta por ciento de su renta de la actividad agraria. En este punto la Ley va más allá del requisito de renta exigido por la Ley 19/1995, de Modernización de Explotaciones Agrarias, para ser, a los efectos de ese texto legal, agricultor profesional y parece indicar que deben ser agricultores a título principal, definidos en relación a la procedencia de sus rentas y el tiempo dedicado a actividades agrarias $^{82}$.

u) En cuanto a los tres vocales en representación de los ganaderos de la provincia,

${ }^{8 \mathrm{I}}$ Artículo 6 de la Ley 7/2000 de 23-II-2000, de Ordenación del Aprovechamiento de Pastos, Hierbas y Rastrojeras de Castilla-La Mancha.

${ }^{82}$ Artículo 2.6 de la Ley I9/I995, de 4 de julio, de Modernización de las Explotaciones Agrarias. 
con explotación o explotaciones pecuarias en cualquier término municipal de la provincia o con pastos adjudicados en alguno de los municipios de la provincia. Estos ganaderos para poder ser nombrados por el Delegado provincial de la Consejería competente en materia de Agricultura, y Ganadería, a propuesta de las organizaciones profesionales agrarias más representativas del ámbito provincial o regional, tienen que: contar con cartilla ganadera actualizada, llevar un libro de registro de explotación actualizado y estar al corriente de pagos por los pastos adjudicados ${ }^{8_{3}}, \mathrm{y}$ además se requiere que las «rentas que perciban procedan exclusiva o mayoritariamente del sector respectivo al que representa», es decir, que obtiene más del cincuenta por ciento de su renta de la actividad pecuaria.

Plantea el legislador el supuesto en que no existiese propuesta para alguno o algunos de los puestos a cubrir -representantes de los propietario de tierras sujetas al régimen de ordenación de pastos o de los representantes de los ganaderos adjudicatarios de los mismos- por parte de las organizaciones profesionales agrarias más representativas, de ámbito provincial o regional. En tal caso, los vocales representantes serán designados por el Delegado Provincial con competencias en materia de agricultura y ganadería ${ }^{84}$. Sin embargo, no se especifica entre quienes puede el Delegado realizar las designación. Entiendo que las designación se realizará entre quienes se dediquen profesionalmente a la actividad agraria y que sean propietarios de la tierras sujetas a ordenación en cualquier término municipal de la provincia. En cuanto a los tres vocales en representación de los ganaderos de la provincia, se designarán entre quienes con explotación o explotaciones pecuarias en cualquier término municipal de la provincia o con pastos adjudicados en alguno de los municipios de la provincia, cuyas rentas que perciban procedan exclusiva o mayoritariamente -obtiene más del cincuenta por ciento- de la actividad pecuaria.

v) También formará parte de las Comisiones Provinciales de Pastos, el secretario, nombrado por el presidente, de entre los funcionarios de la Delegación provincial con competencias en materia de agricultura y ganadería. Hubiese sido conveniente, que el Secretario, además de funcionario, fuese letrado, en aras de poder asesorar legalmente a la Comisión Provincial en sus debates y toma de decisiones.

En cuanto a las competencias de las Comisiones Provinciales de Pastos, el artículo 8 la Ley ${ }^{85}$ señala las siguientes:

w) Informar las Ordenanzas y sus modificaciones, propuestas por las Comisiones Locales -artículo 5.a-.

x) Informar las propuestas de las Comisiones Locales en las materias relacionadas con esta Ley, que deban elevarse a la aprobación del Delegado Provincial de la

83 Artículo 4.2.c. de la Ley Castellano-Manchega, 7/2000, de 23-II-2000, de Ordenación del Aprovechamiento de Pastos, Hierbas y Rastrojeras.

${ }^{84}$ Artículo 7.I y 2. de la Ley Castellano-Manchega, 7/2000, de 23-II-2000, de Ordenación del Aprovechamiento de Pastos, Hierbas y Rastrojeras.

${ }^{85}$ Artículo 8 de la Ley Castellano-Manchega, 7/2000, de 23-II-2000, de Ordenación del Aprovechamiento de Pastos, Hierbas y Rastrojeras. 
Consejería competente en materia de agricultura y ganadería. En concreto las propuestas de exclusión e inclusión de fincas en el régimen común de ordenación de pastos ${ }^{86}$, que serán aprobadas por el Delegado provincial (artículo 9.f), y el informe favorable o desfavorable a la agrupación de fincas para que puedan ser excluidas del régimen común de aprovechamiento ( artículos 5.I.p, 9.e y $20 . \mathrm{I})$.

y) Determinar los precios mínimos y máximos que regirán por hectárea en cada comarca ganadera de su provincia, así como los extraordinarios por cosechas deficientes no recolectadas.

A efectos de fijación de los precios mínimos y máximos que han de regir el aprovechamiento de los diferentes tipos de pastos de cada comarca ganadera de su provincia, será preciso clasificar, en el ámbito territorial de cada provincia, los terrenos sometidos al régimen de ordenación común, atendiendo entre otros criterios a la calidad de los pastos, al tipo de cultivo o pasto, a la duración del tiempo del aprovechamiento, a la topografía y a la pluviometría del terreno, etc.

z) Determinar los precios mínimos y máximos de la cuota que se deberá satisfacer por hectárea y por cabeza de ganado de las diversas especies en el caso de piaras concejiles o dulas.

Ha de tenerse presente que los precios máximos y mínimos de la cuota que se deba satisfacer variará según la comarca en la que se encuentre la hectárea, atendiendo a los criterios señalados en el apartado anterior, y por supuesto según la especie de la cabeza de ganado.

La fijación de esta cuota le corresponde, dentro de esos precios mínimos y máximos a las Comisiones Locales -artículo 5.d-. Si existe dula, vecera o piara concejil, el precio por cabeza de las distintas especies que deberá abonar el ganadero, será el equivalente a la cuota así fijada.

aa) A fin de establecer un desarrollo homogéneo de la normativa sobre pastos, hierbas y rastrojeras en toda la Provincia, o en su defecto en zonas de la misma con parecidas $u$ homogéneas características, la Comisión Provincial de pastos establecerá directrices de carácter vinculante dirigidas a las Comisiones Locales de Pastos.

Las Comisiones Provinciales dictarán estas directrices vinculantes como órganos colegiados de la Administración autonómica (integradas dentro de la Consejería de Agricultura y medio Ambiente de la Junta de Comunidades de Castilla-La Mancha), y por tanto con su correspondiente capacidad reglamentaria, y por ende con carácter vinculante.

bb) La determinación del máximo y mínimo de las cargas ganaderas, esto es, el número máximo y mínimo de cabeza de ganado de los distintas especies por hectárea.

cc) Establecer un registro de titulares de explotaciones ganaderas solicitantes de

${ }^{86}$ Artículos 5.j y 9.f. de la Ley Castellano-Manchega, 7/2000, de 23-II-2000, de Ordenación del Aprovechamiento de Pastos, Hierbas y Rastrojeras. 
pastos que hayan sido sancionados o inhabilitados, a efecto de conocimiento de las Comisiones Locales. Por tanto, a las Comisiones Provinciales de Pastos le corresponde crear, organizar y establecer el procedimiento de los actos y hechos inscribibles en el Registro que tendrá por objeto la inclusión de los titulares de explotaciones ganaderas solicitantes de pastos que hayan sido sancionados o inhabilitados, a efectos de que por parte de los órganos competentes para sancionar se de conocimiento de los mismos a las Comisiones Locales. Este registro de carácter administrativo, contará con los libros correspondientes y con sus órganos, que serán los competentes para sancionar, que según el artículo 30 (además de la Comisión Local de Pastos para actos calificados como faltas leves), son la Comisión Provincial de Pastos - para actos calificados como faltas graves- y el Delegado Provincial competente en materia de agricultura y ganadería para faltas calificadas como faltas muy graves.

dd) La revisión o revocación de los acuerdos y resoluciones de las Comisiones Locales, debiendo en todo caso, dar audiencia a las partes afectadas: Comisión Local, por una parte y al propietario de tierras o ganadero por otra. En cuanto a la revisión de los acuerdos y resoluciones, se produce, toda vez, que alguna circunstancia sufre alguna alteración. Así, se evita el resultado injusto que acarrearía el cambio de circunstancias si no fuesen acompañadas de la correspondiente revisión. Para que esta revisión tenga lugar, es preciso que se produzca una resolución administrativa contraria a otra anterior. Por otra parte, la revocación procede de un órgano superior que ejerce funciones revisoras con jerarquía sobre el que produjo el acto revocado, todo ello en base al interés público por el que la Administración debe velar.

Por último, a la Comisión Provincial le corresponde dictar una resolución dirimente en el plazo de un mes, en caso de existir empate, y de persistir este durante un mes, entre los miembros de la Comisión Local -artículo 5.2-.

\section{3. Órganos unipersonales.}

En cuanto a los órganos unipersonales en materia de pastos integrados en la Consejería competente en materia de agricultura y ganadería, el texto legal señala a los Delegados provinciales (artículo 9) y al Consejero (artículo ıo).

Los Delegados Provinciales_de la Consejería competente en materia de agricultura y ganadería tendrán las siguientes competencias:

a) Aprobar las Ordenanzas de pastos, hierbas y rastrojeras de cada localidad, -así como sus correspondientes modificaciones- que habiendo sido propuestas, tras $\mathrm{su}$ redacción, por la correspondiente Comisión Local de pastos, fueron informadas por las Comisiones Provinciales de Pastos. Reglamentariamente se determinarán las actuaciones necesarias para elaborar el proyecto de ordenanzas, así como la correspondiente aprobación o modificación.

Las ordenanzas aprobadas tendrán una duración indefinida, entrando en vigor el primer día del año ganadero siguiente al de su aprobación.

b) Establecer los plazos extraordinarios de retirada de cosecha y paja, dado que los 
plazos ordinarios le corresponde establecerlos a la Comisión Local de pastos en virtud de lo dispuesto en el artículo 5. letra o) del texto legal que se remite al respecto a lo dispuesto al artículo 24 del Decreto I256/1969, de 6 de junio, por el que se aprueba el Reglamento de Pastos, Hierbas y Rastrojeras. El establecimiento de estos plazos, sean ordinarios o extraordinarios, se fijan de cara a la entrada del ganado en las rastrojeras, haciendo posible el aprovechamiento de las rastrojeras de los terrenos sometidos al régimen de ordenación común.

c) Autorizar, en su caso, la quema de rastrojos antes de las fechas establecidas. Como regla general, existe una prohibición de alzado de los rastrojos, salva las excepciones, como la presente autorización. Los rastrojos, como productos secundarios de las cosechas agrícolas que pueden servir como medio de alimentación del ganado extensivo mediante aprovechamiento a diente no pueden eliminarse -o quemarse- antes de la fecha que se determine en la Ordenanza de pastos de cada localidad. Ese plazo establecido, empezará a contarse desde el día siguiente al de la finalización de la recolección del grano en la finca. Excepcionalmente, los Delegados provinciales pueden autorizar la quema antes de las fechas establecidas en atención a que la práctica agronómica aconseje el alzado en fechas inmediatas a la recolección para determinados cultivos, o por circunstancias metereológicas excepcionales de temporales de lluvia en periodos próximos a la cosecha, que aconsejen el aprovechamiento de dichas circunstancias para el alzado.

Por otra parte, los titulares de las explotaciones agrarias, además de no poder quemar ni eliminar de otra manera los rastrojos, tampoco podrán labrar los rastrojos, ni espaciar residuos nitrogenados de origen ganadero, antes de que transcurra el periodo de tiempo indicado en las Ordenanzas.

d) Resolver las peticiones de segregación de superficies que los interesados soliciten para su exclusión del régimen común de ordenación de los pastos, hierbas y rastrojeras, por encontrarse dentro de las situaciones previstas en el artículo 2I.3 del texto legal.

La Delegación Provincial resolverá -artículo 21.2- las peticiones de segregación de fincas a petición de los interesados, salvo las excepciones no autorizables establecidas en las Ordenanzas de Pastos.

e) Resolver las agrupaciones de fincas para su exclusión del régimen común de aprovechamiento, previo informe de la correspondiente Comisión Local artículo 5.p-. Los titulares de fincas rústicas colindantes podrán, previo informe de la Comisión Local y con autorización del Delegado Provincial competente, agrupar sus fincas para que puedan ser excluidas del régimen común de aprovechamiento siempre que se cumpla lo establecido en el artículo 20.I.

f) Resolverá la propuesta de la Comisión Local sobre la exclusión e inclusión de fincas en el régimen común de ordenación de pastos (artículo 5.j), previo informe de la Comisión Provincial de Pastos -artículo 8.b-. Para ello ha de tener presente los usos y costumbres de cada localidad, término municipal o comarca, así como las características especiales de las explotaciones agrarias existentes o la exigua trascendencia de los pastos sometidos a ordenación común. 
g) Ejecutará la recaudación por la vía ejecutiva, ya que el cobro en periodo voluntario lo realizarán las Comisiones Locales de pastos. Se trata de una modalidad del procedimiento recaudatorio que se inicia cuando, vencido el plazo de ingreso voluntario del pago de los pastos por los ganaderos adjudicatarios, no se hubiesen hecho efectivos por los mismos. Para realizar el cobro de los pastos a los ganaderos adjudicatarios una vez vencido el plazo establecido para el pago , no lo hubiesen efectuado. El Delegado Provincial, dictará una resolución que es inmediatamente ejecutiva (la ejecución de su acuerdo se realiza como si se tratase de una resolución ejecutoria judicial).

h) Impartirá instrucciones -normas vinculantes-, a los servicios dependientes de la Delegación en orden a colaborar en las Comisiones Provinciales y Locales de Pastos

Por su parte, el artículo décimo del texto legal, señala que la superior dirección de los órganos de la Administración autonómica en materia de pastos, hierbas y rastrojeras corresponde al Consejero del Gobierno de la Junta de Comunidades de Castilla-La Mancha competente en materia de agricultura y ganadería. Al susodicho Consejero le corresponde resolver, en el plazo de un mes, los recursos de alzada que se interpongan contra los acuerdos de la Comisión Provincial de Pastos y las resoluciones dictadas por el Delegado Provincial, poniendo fin así a la vía administrativa -artículo 25.2-. Además, al mentado Consejero le corresponderá aprobar el Reglamento de la Comisión Provincial de Pastos -artículo iı.2.6-.

En el artículo ir de la Ley se establecen una serie de disposiciones comunes a los órganos unipersonales y pluripersonales competentes en materia de pastos. El funcionamiento de las Comisiones Provinciales de Pastos y las Comisiones Locales de Pastos se ajustará a sus respectivos reglamentos internos y a lo previsto en esta Ley de Pastos Castellano-Manchega, y en lo no previsto en este texto legal, se estará a lo establecido en el Capítulo II, Órganos Colegiados del Título II de la Ley 30/1992, de 26 de noviembre, de Régimen Jurídico de las Administraciones Públicas y del Procedimiento Administrativo Común.

Para la aprobación del Reglamento interno de funcionamiento de la Comisión Local, ésta elaborará una propuesta que será informada por la Comisión Provincial de Pastos y aprobada por el Delegado Provincial con competencia en materia de agricultura y ganadería.

Respecto al Reglamento interno de funcionamiento de la Comisión Provincial de Pastos, ésta elaborará una propuesta de Reglamento que será informado por el Delegado Provincial competente y aprobado, en su caso, por el Consejero competente en materia de agricultura y ganadería.

Sin derecho a participar en las deliberaciones y sin derecho de voto, podrán asistir a las reuniones de la Comisión Local o Provincial de Pastos, personas distintas a los miembros que las componen, para informar sobre asuntos que puedan resultar de especial interés para el desarrollo de las funciones que tales Comisiones tienen asignadas, para lo cual se requiere previa autorización de su respectivo presidente, o bien, que dicha comparecencia sea propuesta al menos por la mayoría simple de la correspondiente Comisión. 
4. De las ordenanzas y del aprovechamiento de pastos.

La ordenanza de pastos, según el artículo i2 del texto legal, será elaborada y aprobada conforme a lo establecido en los artículos 5.I.a), 8.a) y 9.a), y regirá en los respectivos términos municipales sometidos a ordenación común por existir terrenos que pueden ser objeto de aprovechamiento para realizar el pastoreo. Deberá regular como mínimo los siguientes extremos:

I. El número de hectáreas de la extensión superficial total del término municipal según los datos catastrales, indicando las que corresponden al suelo urbano y las que corresponden a suelo rústico. En las hectáreas de suelo rústico, se distinguen los terrenos sometidos a ordenación común de pastos, de los terrenos excluidos de dicha ordenación, especificando la causa: zonas reconocidas como regadío, viñedos, plantaciones frutales, olivares, repoblaciones forestales, montes catalogados de utilidad pública u otros montes conveniados y consorciados, terrenos comunales, terrenos ocupados por descansaderas de ganado, abrevaderos, así como terrenos totalmente improductivos - artículo i9-. Junto a estos terrenos, también cabe excluir otros de la ordenación a instancia de parte: fincas que son susceptibles de aprovechamiento independiente, praderas, fincas cerradas, fincas objeto de aprovechamiento por explotación pecuaria de sus titulares, cultivos de remolacha, patata, huertos.

2. Se especificará el número de explotaciones ganaderas, por especie -vacuno, ovino, caprino, porcino o equino- y su equivalencia en Unidades de Ganado Mayor.

3. El terreno sometido a ordenación común se encuentra dividido a efectos de su aprovechamiento en polígonos, debiendo determinarse la extensión superficial en hectáreas pastables sujetas al régimen de ordenación común, así como sus linderos. En su caso, se indicarán los enclavados existentes, indicando la extensión total en hectáreas y sus referencias catastrales.

La descripción del polígono relacionará la denominación, destino, exclusión superficial en hectáreas pastables sujetas al régimen de ordenación común, delimitación y linderos, vías de acceso al polígono( caminos, veredas o cañadas), enclavados (su número, exclusión total y referencias catastrales), abrevaderos o cauces de agua para el ganado (situación, condiciones de uso y disfrute), albergues para el ganado (ubicación, capacidad, condiciones de uso y disfrute).

4. Se determinará los polígonos existentes destinados a ganado trashumante, así como los enclaves adecuados para ganado enfermo, cuya finalidad es la reclusión del mismo por alguna epizootía.

5. Se fijará el número de hectáreas que precisa para su sostenimiento una Unidad de Ganado Mayor, clasificada por polígonos y por año completo -o temporada de pastos-, sin contar con las crías.

Se especificará el número de hectáreas que precisa una Unidad de Ganado Mayor (U.G.M.) para su sostenimiento, clasificados por polígonos y temporada - 
primavera, verano, otoño e invierno- ${ }^{87}$.

6. Clases de aprovechamiento, épocas, duración y normas sobre las mismas, teniendo presente las costumbres y características locales y comarcales. Las épocas de los distintas clases de aprovechamientos de pastos, hierbas y rastrojeras a efectos de duración podrán dividirse en temporada de primavera, verano, otoño e invierno. Se puede vedar el pastoreo para un polígono o polígonos en determinadas épocas del año ganadero determinado reglamentariamente (vg. el comprendido entre el I5 de mayo de un año y el I4 de mayo del año siguiente).

7. Indicación de las vías pecuarias que discurren por el término municipal, con expresión de su anchura y linderos. Así mismo se indicarán las servidumbres de paso existentes, identificando los predios mediante la expresión de su referencia catastral, en las que se hallan constituidas las servidumbres de paso de ganado.

8. Delimitación del polígono asignado a la dula -si existiese-, así como el régimen de administración y normas que la regulen. Se trata de señalar el polígono o polígonos en los que pastará, si existe la dula, vecera o piara concejil. Se fijarán las normas que regulen su funcionamiento para cada año ganadero, así como otro tipo de normas administrativas sobre el régimen económico de los aprovechamientos.

9. El procedimiento para el cobro de los pastos a los ganaderos y su pago a los propietarios de tierras. Se fijará la gestión del cobro del precio de los pastos por las Comisiones Locales, así como la realización del pago a los propietarios en el plazo que se establezca en proporción a sus respectivas superficies y aprovechamientos, a través, por ejemplo de sus respectivas cuentas corrientes que a tal efecto designen dichos propietarios. Si el propietario de tierras fuese a su vez acreedor y deudor de pastos, en función de su condición de ganadero adjudicatario, se efectuará la liquidación por la diferencia.

Los propietarios de tierras pueden renunciar con anterioridad al inicio de plazo para el pago de los aprovechamientos, y por escrito, al cobro de sus participaciones en el precio de los pastos a favor de la Comisión Local de pastos, debiéndose destinar dichos fondos a finalidades de interés general en el plazo que se señale.

Io.Además las ordenanzas pueden hacer referencia, con sujeción a la presente Ley, a

\footnotetext{
${ }^{87}$ Vide la tabla de conversión de las diferentes especies en U.G.M., Anexo del Decreto 307/1999, de 9 de diciembre por el que se aprueba el Reglamento General de Ordenación de los recursos agropecuarios locales , de la Comunidad Autónoma de Castilla y León (Boletín Oficial de Castilla y León $\mathrm{n}^{\circ} 239$ de I4 de diciembre de I999). Cuando se utiliza la expresión U.G.M. se está indicando un equino de más de seis meses, o un bovino de más de dos años, por ejemplo. Pero esta unidad de medida requiere un tabla de conversión de las diferentes especies en U.G.M. : así vg. en aves, 25 avestruces equivalen a una U.G.M., y una gallina ponedora a o,oI6; en especies cinegéticas, un conejo o liebre a ○,0I4; un bovino de más de seis meses y menos de 2 años equivale a o,6, en caprino, una cabra equivale a 0,15 , un macho adulto a 0,12 un equino de hasta seis meses equivale a 0,6 ; los ovinos, una oveja equivale a 0,15 y machos adultos a $0, \mathrm{II}$; en porcinos, cerdos reproductores a $0,5 \mathrm{y}$ cerdos de engorde a 0,30 y verracos 0,35; y en abejas , 20 colmenas equivalen a una unidad de Ganado Mayor
} 
todos aquellos extremos que puedan servir para la mejora de la gestión y aprovechamiento de pastos y en suma, que produzcan efectos favorables para la ganadería extensiva.

El procedimiento para elaborar y modificar las ordenanzas se señala en el artículo I3. Estarán aprobadas entes de dar comienzo el año ganadero. La propuesta de ordenanza se elaborará por la Comisión Local de Pastos y se expondrá al público en el tablón de anuncios del Ayuntamiento por un plazo mínimo de un mes. Posteriormente, si se han presentado, se resolverán las alegaciones presentadas y se elevará a la Comisión Provincial la propuesta de Ordenanzas, para que las informe en el plazo de un mes desde su recepción. Si no se emitiese informe en el plazo previsto, éste se entenderá favorable. Posteriormente, la Comisión Provincial las remitirá para su aprobación al Delegado Provincial de la Consejería con competencia en materia de agricultura y ganadería en el plazo de un mes a contar desde su recepción. Si no se emitiese resolución alguna en dicho plazo, se entenderá aprobada por silencio administrativo.

Las ordenanzas así aprobadas, serán publicadas en el tablón de anuncios del Ayuntamiento correspondiente. Se publicará un anuncio de dicha exposición en el Diario Oficial de Castilla-La Mancha.

\section{Aprovechamiento de los pastos.}

La Ley, artículos I4 y siguientes, dedica unas disposiciones generales a los pastos y $\mathrm{su}$ aprovechamiento. Se define en primer lugar los pastos como todos aquellos productos procedentes de praderas, eriales o productos secundarios de explotaciones agrícolas o forestales que sean susceptibles de servir como alimento del ganado. Aún cuando el texto legal no lo haga, resulta necesario distinguir entre pastos, hierbas y rastrojeras. Pastos y hierbas son los productos derivados de las praderas naturales, artificiales y de los eriales. Por otra parte, las rastrojeras son los productos secundarios de las explotaciones agrícolas que pueden servir como medio de alimentación del ganado extensivo mediante aprovechamiento a diente. Por otra parte estos productos han de ser susceptibles de servir como alimento del ganado, pero aún cuando no se diga, se refiere a la alimentación del ganado extensivo.

Las formas de adjudicación de los pastos se contemplan en el artículo i5. En primer lugar se ocupa del convenio entre agricultores y ganaderos en fincas que su extensión sea suficiente para el mantenimiento del rebaño base de cabezas de ganado de cada especie en unidades de ganado mayor (U.G.M.).

Igualmente cabe el convenio entre agricultores y ganaderos en fincas que se encuentran excluidas antes de la entrada en vigor de la presente Ley y no hayan perdido la condición por la que fueren excluidas.

Podrán suscribirse convenio de aprovechamiento de pastos en una localidad: de una parte los agricultores titulares de los pastos objeto de aprovechamiento y de otra, los ganaderos de la localidad, o de otra localidad que tuvieran derecho de pastos reconocidos en aquella. Reglamentariamente se fijarán los requisitos necesarios para poder suscribir el convenio, así como el contenido mínimo del mismo, referido al lugar y fecha de suscripción, la identificación de las personas que lo suscriben, el título por el cual ostentan el disfrute de las fincas -y en su caso y a estos efectos, hayan otorgado expresamente los propietarios-, el plazo de duración, la designación de un domicilio a efectos de notificaciones y 
requerimientos, la relación de fincas afectadas por el convenio, especificando su superficie y los titulares de los mismas, el ganadero o ganaderos beneficiados, el número y especie de los animales que habrán de aprovechar los pastos objeto del convenio, relación de las clases de pastos, hierbas y rastrojeras y cualesquiera otros productos vegetales susceptibles de ser aprovechados como forraje, la contraprestación a satisfacer por el aprovechamiento ( si fuese en dinero, se especificará la forma y fecha del pago o pagos; si se pactasen prestaciones no dinerarias, se precisará su naturaleza y valoración), y por último se señalarán las indemnizaciones pactadas en supuestos de incumplimiento de las cláusulas del convenio.

El convenio está sujeto a la aprobación de la Comisión Local -según el artículo 5 f.-, para verificar el cumplimiento de la legislación vigente. Contra su aprobación o denegación del convenio se pueden presentar reclamaciones que serán resueltas por dicha Comisión Local, sin perjuicio de su revisión o revocación, en su caso, de estos acuerdo de la Comisión Local, previa audiencia de las partes afectadas -Comisión Local y propietarios de tierras o ganaderos- que le corresponde a la Comisión Provincial de pastos.

Una segunda forma es la adjudicación directa de los pastos por la Comisión Local de pastos en el supuesto de que no se hubiese celebrado convenio o que celebrado éste no afectara a la totalidad del término municipal sometido a ordenación. Se adjudicará directamente los aprovechamientos a los ganaderos que se encuentren en posesión de la correspondiente documentación oficial y con derechos de pastos reconocidos e inscritos en la localidad de que se trate. A la hora de fijar el precio de la adjudicación directa se establecerá una proporcionalidad entre el número de cabezas de ganado y la extensión del terreno sometido a ordenación del que se disponga. Ha de evitarse que a un mismo ganadero le sean adjudicados terrenos en lugares distintos entre si o separados por accidentes de terreno $u$ otras causas que hagan difícil el aprovechamiento de aquellos.

La adjudicación directa de los aprovechamientos le corresponde a la Comisión Local, sin perjuicio de que la misma pueda ser objeto de recurso ante la Comisión Provincial de Pastos -artículo 8 .h-. La adjudicación directa de los aprovechamientos le corresponde a la Comisión Local, sin perjuicio de que la misma pueda ser objeto de recurso ante la Comisión Provincial de Pastos -artículo 8 .h-.La adjudicación directa de los aprovechamientos le corresponde a la Comisión Local, sin perjuicio de que la misma pueda ser objeto de recurso ante la Comisión Provincial de Pastos -artículo 8 .h-.La adjudicación directa de los aprovechamientos le corresponde a la Comisión Local, sin perjuicio de que la misma pueda ser objeto de recurso ante la Comisión Provincial de Pastos -artículo 8 .h-.La adjudicación directa de los aprovechamientos le corresponde a la Comisión Local, sin perjuicio de que la misma pueda ser objeto de recurso ante la Comisión Provincial de Pastos -artículo 8 .h-.La adjudicación directa de los aprovechamientos le corresponde a la Comisión Local, sin perjuicio de que la misma pueda ser objeto de recurso ante la Comisión Provincial de Pastos ? artículo 8 .h-.La adjudicación directa de los aprovechamientos le corresponde a la Comisión Local, sin perjuicio de que la misma pueda ser objeto de recurso ante la Comisión Provincial de Pastos ? artículo 8 .h-.La adjudicación directa de los aprovechamientos le corresponde a la Comisión Local, sin perjuicio de que la misma pueda ser objeto de recurso ante la Comisión Provincial de Pastos ? artículo 8 .h-.La adjudicación directa de los aprovechamientos le corresponde a la Comisión Local, sin perjuicio de que la misma pueda ser objeto de recurso ante la Comisión Provincial de Pastos ? artículo 8 .h-.La adjudicación directa de los aprovechamientos le corresponde a la Comisión Local, sin perjuicio de que la misma pueda ser objeto de recurso ante la Comisión Provincial de Pastos ? artículo 8 .h-.La adjudicación directa de los aprovechamientos le corresponde a la Comisión Local, sin perjuicio de que la misma pueda ser objeto de recurso ante la Comisión Provincial de Pastos ? artículo 8 .h-. 
Como tercera forma de adjudicación se encuentra la subasta pública cuando no se dé el convenio entre los agricultores y ganaderos o no se produzca la adjudicación directa y haya sobrantes permanentes de pastos. Necesariamente transcurrirá un intervalo entre las adjudicaciones directas y las subastas, para calcular las existencias disponibles y los polígonos correspondientes pero ha de reducirse al mínimo posible para evitar retrasos en el aprovechamiento de los terrenos subastables, que originaría pérdidas para la ganadería y para el valor de los pastos ${ }^{88}$.

Los polígonos de pastos correspondientes se subastarán con un mes de antelación a la fecha en que deba comenzar el aprovechamiento de los mismos. Se anunciaran con quince días de anticipación, por lo menos, en aquellos sitios donde se acostumbre a hacerlo y en el tablón de anuncios del Ayuntamiento en cuyo término municipal se encuentren ubicados los terrenos sometidos a ordenación, especificándose el lugar donde haya de celebrarse la subasta, indicando el día y la hora, expresando el lugar donde se encuentran depositados para su examen los pliegos de condiciones que rigen la misma, referidos a:

I. los terrenos objeto de licitación, esto es, polígono o polígonos, superficies, linderos, tipo de aprovechamiento,

2. la duración de los aprovechamientos, expresando fechas de inicio y finalización de los mismos,

3. el tipo de subasta para la licitación al alza,

4. la forma de celebración de la subasta, que es la puja a la llana y,

5. la forma de adjudicar el remate y el sistema de pago del importe de la adjudicación.

Los anuncios de las subastas, además de aquellos sitios donde se acostumbre a hacerlo, puede ser útil anunciar también la subasta en algún periódico provincial. En todo caso estos anuncios serán breves, indicando además del día, hora y lugar en que haya de tener efecto la subasta, extensión, precio y situaciones, la naturaleza de los pastos (hierbas, pastos o rastrojeras) y la época de los aprovechamientos. En cuanto a los pliegos de condiciones, serán como el propio negocio jurídico que se desarrolla, sencillos, indicando, además de las condiciones expuestas en el anuncio, las fechas de entrada y salida e los ganados, topes de ganado permitido, etc ${ }^{89}$.

La subasta que será pública se celebrará por la Comisión Local -artículo 5. f- y para cada polígono separadamente por el procedimiento de pujas a la llana ${ }^{90}$, levantándose el

${ }^{88}$ NieTO, A. , Ordenación de Pastos, Hierbas y rastrojeras, Tomo II, Junta Provincial de Fomento Pecuario de Valladolid, Valladolid, I959, p. 302.

${ }^{89}$ A la licitación de pastos mediante subasta pública podrá acudir cualquier titular de explotación pecuaria permanente en el término municipal Cfr. el artículo 69.I del Decreto I256/i969, de 6 de junio, por el que se aprueba el Reglamento de Pastos, Hierbas y Rastrojeras, previa acreditación de la correspondiente cartilla ganadera. La explotación pecuaria, acreditada mediante la correspondiente cartilla ganadera, está referida al ganado lanar que vaya a realizar los aprovechamientos de pastos, Artículo 63 del Decreto I256/1969, de 6 de junio, por el que se aprueba el Reglamento de Pastos, Hierbas y Rastrojeras. NIETO, A. , Ordenación de Pastos, Hierbas y rastrojeras, Tomo II, Junta Provincial de Fomento Pecuario de Valladolid, Valladolid, I959, p.305.

${ }^{90}$ Artículo 70 del Decreto I256/ı969, de 6 de junio, por el que se aprueba el Reglamento de Pastos, Hierbas y Rastrojeras. 
correspondiente acta.

Se celebrará una primera subasta de pastos, a la que únicamente podrán concurrir los ganaderos del término municipal ${ }^{9 \mathrm{r}}$, inscritos en el registro público de ganaderos confeccionado por la Comisión Local (artículo 5.c ), que no hayan obtenido por adjudicación directa la totalidad de los pastos que corresponderían al cupo de ganado reconocido a cada uno de ellos. Esta primera subasta tiene carácter subsidiario del convenio entre agricultores y ganaderos o mediante adjudicación por la Comisión Local de pastos. Del propio artículo I5 de la Ley de pastos Castellano-Manchega se deduce que no estamos ante una subasta «libre» de pastos entre ganaderos locales, sino que la subasta pública está pensada cuando haya sobrantes permanentes de pastos y no se den convenios entre agricultores y ganaderos $o$ mediante adjudicación por la Comisión Local de pastos. Por lo tanto, aquellos ganaderos que ya tengan acomodado su ganado en el terreno de pastos, bien a través de un convenio con agricultores o bien mediante adjudicación por la Comisión Local de Pastos, no concurrirán a la subasta, abierta únicamente a los ganaderos, que no habiendo llegado por otra forma a acomodarse en el terreno, recurren a esta forma de adjudicación para determinarlo.

A cada ganadero adjudicatario sólo podrá corresponderle el polígono o fracción de éste que sea capaz de alimentar el número de cabezas de ganado en derecho inscrito y cuya posesión acredite en las cartillas ganaderas. Los ganaderos con cupos inferiores al rebaño base podrán agruparse entre si para poder pujar.

En el caso de quedar pastos sin adjudicar en la primera subasta, se celebrará una segunda, diez días más tarde, a la que podrán concurrir los ganaderos del término municipal o de cualquier otro ${ }^{92}$. Se trata por tanto de una subasta de naturaleza distinta a la anterior, ya que la segunda es libre al equipararse los ganaderos del término con los forasteros. En cuanto a la forma de la subasta, es sustancialmente la misma que la de la primera, salvo pequeñas diferencias, como por ejemplo, la mayor utilidad de la publicación del anuncio de subasta en algún periódico de la provincia o de zonas limítrofes, al objeto de que aumente el número de licitadores. Si la segunda se declarara desierta, los pastos se considerarán como sobrantes temporales para su utilización hasta el siguiente año ganadero, según proponga la Comisión Local a la Comisión Provincial de Pastos.

Por último, el aparto segundo del artículo I5, contempla la posibilidad de realizar adjudicaciones extraordinarias de los terrenos sobrantes que no hayan sido adjudicados mediante convenio, adjudicación por la Comisión Local y Subasta Pública, todo ello con la finalidad de facilitar el mejor aprovechamiento de los pastos.

En el artículo I6, en aras de salvaguardar la adecuada sanidad animal, prohíbe adjudicar el aprovechamiento de pastos sometidos a ordenación común o comunales a aquellos ganaderos cuyos animales procedan de explotaciones que no tengan la calificación sanitaria requerida para mover libremente su ganado o cuyos animales no se encuentren identificados de acuerdo con la normativa vigente. Únicamente podrán acceder a este régimen de aprovechamiento de pastos, los ganaderos cuyos animales procedan de explotaciones que guarden en todo momento la normativa vigente sobre sanidad, identificación y registro animal.

\footnotetext{
${ }^{9 r}$ Artículo 7I del Decreto I256/1969, de 6 de junio, por el que se aprueba el Reglamento de Pastos, Hierbas y Rastrojeras.

${ }^{92}$ Artículo 72 del Decreto 1256/ig69, de 6 de junio, por el que se aprueba el Reglamento de Pastos, Hierbas y Rastrojeras.
} 
En el artículo I7, se establece una preferencia respecto de las pastos a adjudicar, así como respecto de los adjudicatarios. En cuanto a los pastos, serán los comunales los primeros pastos que se adjudicarán, debiendo asignar a cada ganadero residente, las hectáreas de pastos que le correspondan en función de las Unidades de Ganado Mayor de que disponga, siendo entonces cuando podrán adjudicarse pastos a ganaderos de municipios limítrofes. Posteriormente a los pastos comunales, se repartirán el resto de superficies no excluidas, ni segregadas, teniendo preferencia las explotaciones ganaderas del municipio respecto a las de los municipios limítrofes, y luego las de éstos respecto a las demás.

Respecto de la preferencia de los ganaderos, si dentro del mismo orden de preferencia -primero los comunales, posteriormente el resto de superficies no excluidas ni segregadas- coinciden solicitudes sobre el mismo polígono, que superan la carga ganadera establecida por la Comisión Local o la que rige para esa zona, se dará preferencia, primero a los ganaderos que pertenezcan a una Cooperativa de explotación ganadera y formen parte de una Agrupación de Defensa Sanitaria Ganadera y después, en segundo lugar a los ganaderos que las tuvieren adjudicadas en años anteriores -artículo I7.3-.

De las superficies incluidas y excluidas de la Ordenación Común de Pastos, se ocupan los artículos I8 y i9 de la Ley. Según dispone el primero de los preceptos, los terrenos incluidos en la Ordenación Común de Pastos, son las superficies agrarias productivas, los pastos comunales y las superficies destinadas tradicionalmente al pastoreo que no sean expresamente excluidas.

Además de los terrenos incluidos en las vías pecuarias, en los que el aprovechamiento de los pastos es libre -artículo I8.2-, quedan excluidos de la Ordenación común del aprovechamiento de los pastos según el artículo I9:

a) Las huertas y las zonas que ostenten la condición de regadío, cuando se hayan regado en una de las dos últimas campañas. A estos efectos de la Ley, se consideran regadíos los de carácter permanente y/o intensivos, sin que en ningún caso queden comprendidos dentro los mismos, los cultivos herbáceos. Por tanto, quedan excluidos del aprovechamiento de pastos, los cultivos de remolacha, patata y otros intensivos de regadío en cada campaña. La razón de esta exclusión se basa en la intensidad del cultivo, ya que la pausa de descanso de la tierra impide la entrada de ganados. Sin embargo, esta razón no cabe en las explotaciones de cereales en fincas de regadío.

b) Las superficies plantadas de viñedos, olivares y frutales. Aún cuando el hojadero de la vid pudiera ser un aprovechamiento para el ganado lanar, los viñedos no son objeto de la Ordenación Común de aprovechamiento. Ahora bien, ello no excluye la posibilidad de realizar un contrato de arrendamiento entre el propietario de la viña y el ganadero para el aprovechamiento del hojadero de la viña.

En estos casos, la exclusión se basa en los daños que puede causar el ganado en las cepas de la viña ( o en su caso, los árboles), particularmente en las plantaciones recientes.

Puede ocurrir que sólo una parte de la finca sea de regadío, o sólo parcialmente esté plantada de viñedo, olivar o frutales. En tales casos, «se excluirá toda la finca de la Ordenación Común de Pastos o sólo la parte afectada». En mi opinión, habrá que estar a la importancia de la parte afectada respecto del total de la finca. Si esa relevancia no fuese suficiente, no ha de respetarse la integridad de la finca, por no 
existir una clara individualización de las porciones de la parcela respecto a la naturaleza de sus pastos. Por tanto, puede llegarse perfectamente a la situación en que dentro de una misma finca, una parte de la misma esté excluida de la susodicha Ordenación y la otra, en cambio, esté incluida.

c) Los montes catalogados de Utilidad Pública, los Conveniados y Consorciados, salvo informe contrario del órgano competente.

d) Las fincas cercadas de modo permanente mediante setos vivos o de obra. Se refiere el texto legal, a las fincas cercadas artificialmente al rodearlas por muros, cercas, vallas, o cualquier obra para impedir el acceso. No existe justificación para excluir igualmente a las fincas cerradas en su totalidad con carácter permanente aún cuando sea de forma natural, al estar rodeadas las fincas por corrientes permanentes y profundas de aguas $u$ otros accidentes topográficos que impidan en paso del ganado.

e) Las fincas enclavadas en regadío, en viñedos, olivares, frutales, montes catalogados de Utilidad Pública, los Conveniados y Consorciados, o en fincas cercadas de modo permanente mediante setos vivos o de obra.

Todas las superficies enumeradas, excepto los montes catalógados de utilidad pública, los Conveniados y Consorciados, podrán ser aprovechados con el consentimiento escrito del titular -artículo I9.2-. Ahora bien, si bien al amparo de esta Ley se abandona o renuncia al derecho de exclusión de las superficies susodichas en beneficio de los ganaderos, sin embargo, en cualquier tiempo que sea el titular de la superficie puede cambiar de parecer y puede reclamar la exclusión.

El artículo 20, se ocupa de la agrupación de fincas. Previo informe de la Comisión Local y con la autorización de la Delegación Provincial competente, los titulares de fincas rústicas colindantes pueden agrupar sus fincas para que sean excluidas del régimen común de aprovechamiento siempre que:

a) el aprovechamiento de sus fincas agrupadas se efectúe por ganado que posean o adquieran legalmente los titulares de las fincas agrupadas.

b) las fincas formen un coto bien delimitado y no obstaculice los demás aprovechamientos. Las características de la extensión de la agrupación permiten un aprovechamiento independiente de sus pastos.

c) se pueda sustentar un número de Unidades Ganado Mayor mínimo que fija la Delegación Provincial Competente.

Aún cuando no lo diga la Ley, este aprovechamiento de fincas agrupadas no puede impedir el acceso del ganado a los terrenos sometidos al régimen de ordenación común de pastos, y han de tener estas fincas accesos independientes, sin que los rebaños que los pasten invadan las fincas colindantes donde se encuentren ubicados.

El aprovechamiento de pastos, hierbas y rastrojeras de las fincas agrupadas no puede cederse, ni subarrendarse a terceros ajenos a dichas fincas -artículo 20.2-.

Segregar es lo contrario de agrupar, es decir, separar unas superficies de otras. No obstante, ambas figuras pretenden la misma finalidad: la exclusión de determinadas 
superficies del régimen común del aprovechamiento de los pastos. Las peticiones de segregación de superficies se formularán con al menos con tres meses de antelación al año ganadero y especificando la razón de segregación, se formularán ante los Delegados Provinciales competentes, quienes las resolverán teniendo presente las excepciones no autorizables establecidas en las Ordenanzas de Pastos.

Para que las fincas puedan segregarse deberán encontrarse en alguna de las situaciones previstas en el artículo 21.3:

a) fincas que por sus características o condiciones no deban ser destinadas a los aprovechamientos ganaderos,

b) fincas que hallándose bajo una misma linde sean objeto de explotación ganadera de los aprovechamientos de pastos por su propio titular, con una carga ganadera anual mínima de 30 Unidades de Ganado Mayor según la carga ganadera que en cada caso establezca la Comisión Local de pastos -artículo 5.e-

c) fincas que bajo una misma linde o fincas colindantes unas con otras, formando un conjunto -coto o polígono- sean objeto de aprovechamiento ganadero independiente, mediante acuerdo privado del propietario o cultivador con el ganadero y admitan un aprovechamiento mínimo de 35 Unidades de Ganado Mayor según la carga ganadera que en cada caso establezca la Comisión Local de pastos. Estos acuerdos pueden suscribirse por agrupaciones de agricultores o de ganaderos o de ambos conjuntamente, y en tal concepto de acuerdos entre particulares, cualquier conflicto que pueda suscitarse entre las partes contratantes se resolverá en la jurisdicción ordinaria.

Si la Delegación Provincial que ha concedido la segregación, tuviese conocimiento del incumplimiento de las situaciones establecidas como requisitos en el artículo 21.3, debe anular las susodichas segregaciones por incumplimiento de las situaciones legalmente previstas.

\section{Aislamiento de ganado.}

Ante la situación excepcional por surgir una epizootía en una localidad, término municipal o comarca, que conforme a la legislación vigente imponga un aislamiento restricción al movimiento- del ganado afectado, y previo informe veterinario oficial, la Comisión Local de Pastos acotará los terrenos adjudicados a los ganaderos afectados, previa comunicación al Consejero competente en materia de agricultura y ganadería.

Los terrenos así acotados quedarán excluidos provisionalmente del régimen de ordenación común de pastos mientras permanezcan en los mismos el ganado afectado, no pudiendo ser levantada tal exclusión hasta que la autoridad competente levante las restricciones impuestas con motivo de la declaración de epizootía, previa certificación por el servicio veterinario oficial de que los terrenos pueden ser aprovechados de nuevo, sin peligro de contagio.

El dueño del ganado enfermo abonará el importe de los pastos que aproveche en 
proporción a la superficie acotada y al tiempo que dichos terrenos estuvieren a disposición del ganado afectado, sin poder ser aprovechado por el resto de las ganaderías que sufren, como consecuencia del confinamiento obligatorio del ganado enfermo, una reducción de los pastos que les hubiesen sido asignados.

7. Régimen económico del aprovechamiento de pastos.

De la fijación de precios se ocupa el artículo 23 al establecer que las Comisiones Provinciales de Pastos -artículo 8 c. y d. - determinarán anualmente, en todo caso tres meses antes del comienzo del nuevo año ganadero, los precios máximos y mínimos que regirán durante el mismo, por hectárea y por cabeza de ganado, en las zonas ganaderas de su provincia y teniendo en cuenta la cantidad y calidad de los mismos.

Con el señalamiento anualmente de los precios máximos y mínimos por las Comisiones Provinciales de Pastos se pretende, además de una uniformidad en los precios, un control no sólo sobre las Comisiones Locales de Pastos, sino también sobre el desarrollo de la tasación. La uniformidad de los precios debe dejar un margen flexible atendiendo a que el precio de los pastos están sujetos a las variaciones del mercado y de los productos.

Los precios máximos y mínimos lo serán para todo el año ganadero, lapso superior a seis meses, y nunca en relación a las diferentes temporadas, puesto que es sabido el privilegio que la naturaleza ofrece en una época -vg. primavera-, respecto de otras.

Por otra parte, los precios máximos y mínimos lo serán para cada zona ganadera de la provincia. La determinación de estas zonas ganaderas provinciales no es fácil puesto que por muy homogéneas que sean las provincias, dentro de ellas existen zonas distintas que obligan a diferentes tratamientos en los precios.

Por último, dentro de cada zona ganadera de la provincia, los precios máximos y mínimos de los pastos se fijarán por hectárea y cabeza de ganado según la calidad y cantidad de los pastos. Por tanto, en principio, dos son los elementos de valoración a la hora de determinar los precios máximos y mínimos: la calidad y abundancia de los pastos, a la que creo ha de añadirse, en mi opinión, la naturaleza de las hierbas, restrojos, barbechos, páramos, vegas. ${ }^{93}$

Los precios se concretan en función de la forma de aprovechamiento en el artículo 24:

a) Si la adjudicación de los pastos se realiza mediante convenio entre agricultores y ganaderos, la fijación del precio queda a la libertad de las partes.

93 Atrás quedan otros criterios como el de GALINDO, F., Sobre valoración de pastos, Boletín de la Junta Provincial de la F.P. de León, n I6, junio I957, hace referencia a la unidad alimentaria . Para calcular las necesidades de transformación de un animal se calculan los elementos de sus pastos y de sus piensos en relación a la «unidad alimentaria»: el valor de los pastos no puede exceder del 50\% de sus necesidades referidas a las unidades alimentarias, es decir, que calculando las necesidades alimenticias de un animal y su costo de alimentación si se mantuviese todo el año a cebada, el valor de los pastos que en el año, o en cada temporada consume, no puede exceder de lo que cueste en el mismo tiempo su pienso en régimen de estabulación y cebada. 
b) Si la adjudicación de lo pastos es directa o en subasta, se tendrá en cuenta el precio fijado por la Comisión Local, dentro de los límites establecidos por la Comisión Provincial de Pastos.

c) Si se produce una contratación directa de pastos no adjudicada en subasta, el precio de adjudicación no estará sujeto a mínimo alguno.

8. Impugnación de los acuerdos.

En el artículo 25 del texto legal se contemplan los recursos previstos. Por una parte, los acuerdos de las Comisiones Locales de Pastos serán recurribles en alzada en el plazo de un mes ante la Comisión Provincial de Pastos, cuya resolución pondrá fin a la vía administrativa y por ende deja expedita la vía contencioso administrativa. En segundo lugar, los acuerdos de las Comisiones Provinciales de Pastos y de los Delegados Provinciales competentes por razón de la materia, serán recurribles en alzada en el plazo de un mes ante el Consejero con competencia en materia de agricultura y ganadería, cuya resolución agotará la vía administrativa y abre la puerta de la jurisdicción contencioso administrativa.

\section{Régimen sancionador.}

La ley establece en el artículo 26 y siguientes los tipos de infracciones, sanciones y los órganos competentes para su imposición.

En cuanto el ejercicio de la potestad sancionadora, se ejercerá de conformidad con lo establecido por la legislación básica estatal, es decir, conforme a la Ley 30/1992 de Régimen Jurídico de las Administraciones Públicas y Procedimiento Administrativo Común. No obstante, el instructor, cuyo nombramiento corresponderá en todo caso a la Comisión Local de Pastos, remitirá al órgano competente para imponer la sanción, las actuaciones practicadas, así como la propuesta correspondiente -artículo $26-$.

Las infracciones se tipifican, según el artículo 27, en faltas leves, graves y muy graves.

Se consideran faltas leves: a) el pastoreo, sin consentimiento del propietario o cultivador, de superficies no adjudicadas o excluidas, siempre que hayan sido identificadas y no haya sido superior a una hectárea; b) el pastoreo excesivo sin que sea superior a un I०\% de las condiciones de la adjudicación definitiva, c) la no comunicación por parte del adjudicatario la no utilización de pastos adjudicados; d) no comunicar, en ausencia de mala fe, a la Comisión Local de Pastos las modificaciones sobrevenidas en las condiciones de la adjudicación o de los contratos sobre los pastos.

Se consideraran faltas graves: a) el pastoreo de superficies excluidas o no adjudicadas, produciendo daños en más de una hectárea y menos de cinco; b)el pastoreo de superficies segregadas, siempre que estén debidamente identificadas; c) el pastoreo excesivo, esto es, aquel que exceda del ıо\% de las condiciones de la adjudicación definitiva; d) el levantamiento o quema de rastrojos anticipados cuando afecte a menos de ro hectáreas; e) la aportación de datos falsos con el objeto de conseguir una adjudicación; f) la 
aportación de datos falsos en las solicitudes de segregación o en los contratos de segregación; g) el impago del importe de los pastos; h) la cesión o subarriendo de los pastos adjudicados; i) el pastoreo careciendo de adjudicación; j) la entrada de ganado en terrenos con cultivos o en los barbechos labrados y preparados para la siembra o tras lluvias intensas y recientes; k) la entrada del ganado en fincas, una vez levantada la cosecha antes de que expire el plazo establecido por la Comisión Local; 1) no comunicar a la Comisión Local de Pastos, mediando mala fe, las modificaciones sobrevenidas en las condiciones de la adjudicación o de los contratos sobre pastos; $\mathrm{m}$ ) el pastoreo con animales no identificados de acuerdo con la normativa vigente; $n$ ) el abandono de animales muertos; o) la comisión de tres faltas leves en dos años.

Se consideran faltas muy graves -artículo 27.3-: a)el pastoreo de superficies excluidas, produciendo daños en más de cinco hectáreas; b) el pastoreo reiterado de superficies excluidas o no adjudicadas; c) el pastoreo con animales enfermos o sospechosos de estarlo y abandono de animales muertos con riesgo sanitario para la población, así como no respetar las restricciones sanitarias o de movimiento establecidas por la autoridad competente; d) el levantamiento o quema de restrojos de forma anticipada cuando afecte a más de io hectáreas; e) la simulación de contratos para segregar fincas indebidamente o la comunicación de datos falsos con la misma finalidad; f) la comisión de cinco faltas graves en tres años.

«Quiénes responderán de estas infracciones». Serán responsables las personas que hayan participado en los hechos, ya sea por acción u omisión. Cuando sean dos o más las personas participantes en los hechos que constituyan una infracción, todas ellas responderán solidariamente, por lo que podrá ser exigida a cualquiera de ellas indistintamente -artículo 28 -.

En cuanto a las SANCIONES, el artículo 29, señala que por la comisión de actos calificados como a) faltas leves, se impondrá multa de 60,10 a 300,50 euros; b) faltas graves, se impondrá multa de 300,51 a 1803,03 euros; c) faltas muy graves, se impondrá multa de I803,04 a 60I0,I2 euros y accesoriamente podrá imponerse la sanción de pérdida de la adjudicación de pastos o del derecho a concurrir a las adjudicaciones del año siguiente.

En cuanto al CoBRo DE LAS MULTAS -y demás cantidades adeudadas, vg. lo debido por los ganaderos en concepto de pastos, en caso de no hacerlo en periodo voluntario-, se estará a lo dispuesto en la correspondiente legislación tributaria y de recaudación para la vía ejecutiva. A estos efectos, una vez firme la sanción, se remitirá a la Delegación Provincial con competencia en materia de agricultura y ganadería a fin de que se proceda al cobro de la misma mediante el procedimiento legalmente establecido.

Respecto del IMPAGO DEL IMPORTE DE LOS PASTOS por parte de los adjudicatarios, una vez transcurrido el plazo establecido para ello, dará lugar a la pérdida de la adjudicación y a la inhabilitación del infractor para la concurrencia a pastos del siguiente año ganadero, haciéndose constar ante la Comisión Local encargada de proceder a la inhabilitación correspondiente.

En el cado de que se hubiesen cometido infracciones graves y muy graves además de las multas, podrá imponerse la exclusión de la adjudicación de pastos por un periodo de hasta tres años y la pérdida del derecho a pastos -artículo 29-.

En cuanto a los órganos competentes para imponer sanciones, el artículo 30, 
señala a la Comisión Local de Pastos para los actos calificados como faltas leves; la Comisión Provincial de Pastos para los actos calificados como faltas graves y por último, el Delegado Provincial con competencias en materia de agricultura y ganadería, para los actos calificados como faltas muy graves.

El importe de lo recaudado en concepto de sanciones deberá destinarse a fines de interés general agrario -como vg. arreglo de caminos rurales- del termino municipal correspondiente -artículo 3I- .

El artículo 32, se ocupa de la prescripción de las infracciones y de las sanciones y alude también a la caducidad de las acciones para perseguir las infracciones.

Empezando por este último plazo de caducidad, quien tiene la competencia para iniciar el procedimiento sancionador -la Comisión Local, la Comisión Provincial de Pastos o el Delegado Provincial correspondiente-, disponen de un año, sin posibilidad de interrupción, desde que conocieron los hechos para iniciar las acciones para perseguir las infracciones. Caso de no ejercer durante este plazo, acción alguna tendente a perseguir las infracciones, caducará la posibilidad de ejercitarlas. Se limita temporalmente a un año, sin posibilidad de interrupción, le posibilidad de la facultad de iniciar las acciones para perseguir las infracciones, extinguiéndose a la decadencia del plazo.

En cuanto a la prescripción extintiva, el artículo I930.2 del Código Civil establece que -se extinguen- por prescripción de los derechos y las acciones, de cualquier clase que sean. Alude así a la figura de la prescripción extintiva, requiriendo para su operatividad que : el derecho sea prescriptible -claramente los son los derechos subjetivos patrimoniales-, permanezca inactivo -no ejercitado, pudiéndolo haber sido- y que transcurra el plazo señalado por la ley sin ejercitarse el derecho. Si todo ello sucede, si se produce un acto extemporáneo de pretendido ejercicio del derecho, el sujeto pasivo, podrá alegar la prescripción extintiva, salvo que renuncie a la misma. No obstante, el titular de la facultad que permanece inactivo puede ejercitar eficazmente su derecho mientras no venza el plazo de prescripción. Cuando dentro del plazo, ocurre cualquier acto de ejercicio del derecho, entonces el discurrir del plazo cesa -se interrumpe-, y otra vez comienza desde el principio, si tras ese acto de ejercicio se inicia otra etapa nueva de inactividad.

La Ley pastueña castellana-manchega, distingue entre la prescripción de las infracciones -del acto ilícito -y de las sanciones - multas-. En cuanto a las primeras, las infracciones leves prescribirán a los seis de la comisión del acto ilícito, las graves a los dos años y las muy graves a los tres años de la comisión del acto ilícito. Respecto de la prescripción de las multas impuestas pero no cobradas, las sanciones impuestas por las faltas leves prescribirán al año, las impuestas por las faltas graves, prescribirán a los dos años y las impuestas por faltas muy graves, prescribirán a los tres años. Pasados estos plazos sin ejercer las acciones para sancionar las infracciones, o bien, una vez impuestas las sanciones, no cobrar las multas, pudiendo hacerlo, habrá prescrito respectivamente las infracciones y las sanciones, de tal manera que si el titular de estas facultades pretenda un acto extemporáneo de ejercicio del mismo, el infractor, o el sancionado en su caso, podrá alegar la prescripción extintiva, salvo que renuncie a la misma. 
Io. Disposiciones adicionales, transitorias y finales.

EN LAS DISPOSICIONES ADICIONALES se suelen incluir, y esta Ley no es una excepción, los regimenes jurídicos especiales que no pueden situarse en el texto articulado, los mandatos y autorizaciones no dirigidos a la producción de normas jurídicas, así como los preceptos residuales que no quepan en otro lugar de la nueva Ley.

En la primera, se establece el plazo para la constitución de las Comisiones Locales de Pastos y de las Comisiones Provinciales de Pastos, que será de tres meses a contar desde la vigencia de la presente Ley (a partir del día 25 de diciembre de 2000 , es decir, el 26 de marzo de 200I), rigiendo igual plazo de tres meses para la constitución de la sucesivas Comisiones Locales y Provinciales pero computando el plazo desde la fecha en que expiró el mandato de la Comisión respectiva.

En la segunda, se dispone que si en algún municipio de Castilla-La Mancha no contase con Concejales suficientes para cubrir todos los puestos que hipotéticamente pudieran quedar vacantes por falta de representación de las Organizaciones Profesionales Agrarias o de las propuestas correspondiente (vide lo dispuesto en el artículo 4), las Comisiones Locales de Pastos quedarán constituidas por un número igual al de los Concejales del respectivo Ayuntamiento. En su caso, si fuese preciso por ser inferior a seis el número de concejales del Ayuntamiento que pudiesen ser designados vocales de la Comisión, el Ayuntamiento nombrará un miembro más, (aparte de los cinco Concejales número mínimo que tiene un Municipio según el artículo I79.I de la Ley Orgánica 5/1985, de I9 de junio, del Régimen Electoral General), al objeto de que la representación de los Agricultores (tres vocales) y Ganaderos ( tres vocales) sea paritaria.

Sin embargo, nada dice la Ley pastueña respecto a las Entidades de ámbito territorial inferior al Municipio para la administración descentralizada de núcleos de población separados, bajo su denominación tradicional de aldeas, concejos, pedanías, (artículo 45 de la Ley 7/1985, de 2 de abril, reguladora de las bases de Régimen Local), particularmente en el caso en que se hay establecido el funcionamiento de la entidad en régimen de Concejo Abierto (artículo I99.7 de la Ley Orgánica 5/1985, de I9 de junio, del Régimen Electoral General).

En cuanto a la disposición transitoria tercera, me parece de suma importancia: «Las competencias que el Reglamento de Pastos, Hierbas y Rastrojeras, aprobado por Decreto I256/1969 de 6 de junio, atribuye a las Hermandades Sindicales Locales de labradores y Agricultores y a las Comisiones Mixtas quedan atribuidas a las Comisiones Locales de Pastos; las asignadas a las Juntas Provinciales de Fomento Pecuario a las Comisiones Provinciales de Pastos; las asignadas a la Junta Central de Fomento Pecuario y Dirección General de Ganadería, al Delegado Provincial con competencias en agricultura y ganadería; y las asignadas al Ministro de Agricultura, al Consejero competente en materia de agricultura y ganadería, con las correspondientes adecuaciones, en su caso, establecidas por la presente Ley». Por tanto, esta disposición transitoria tercera nos indica que, si bien con las correspondientes adecuaciones establecidas por la ley pastueña castellano-manchega, el Reglamento de Pastos, hierbas y Rastrojeras aprobado por Decreto I256/1969, de 6 de junio, constituye Derecho estatal supletorio del Derecho de la Comunidades Autónoma CastellanoManchega, siguiendo lo establecido en el artículo I49.3 de la Constitución Española de I978. Con ello quiero indicar que el Reglamento estatal de I969 esta llamado a llenar -con las correspondientes adecuaciones, en su caso, establecidas por la presente Ley- las lagunas provocadas por la falta de Derecho autonómico de Castilla-La Mancha en el ámbito de las competencias autonómicas sobre pastos. La carencia de regulación se da en extremos que 
pueden ser regulado por el Derecho Autonómico, al tener la Comunidad de Castilla-La Mancha competencia para ello, si bien la propia ley pastueña castellano- manchega señala que la disponibilidad de la materia por el Ordenamiento suplido ha de aplicarse con las correspondientes adecuaciones en su caso establecidas en la propia ley pastueña ${ }^{94}$.

Las Disposiciones Transitorias, en este caso, para facilitar la aplicación definitiva de la Ley nueva, regulan de modo autónomo y provisional situaciones jurídicas que se produzcan después de su entrada en vigor. Así, la Disposición Transitoria primera, establece que durante el primer año desde la entrada en vigor de la Ley pastueña, no se exigirá la certificación de la Comisión Local de Pastos para hacer constar, a estos efectos, la condición de propietario de tierras sujetas al régimen al régimen de ordenación de pastos del termino municipal, prevista en el artículo 4.4. párrafo segundo.

En la disposición transitoria segunda, establece que en tanto en cuento se aprueben las respectivas Ordenanzas de pastos, hierbas y rastrojeras, las Comisiones Locales de Pastos acordarán las fechas y plazos de solicitud de pastos, así como los plazos de cobro y pago de los derechos económicos.

La disposición transitoria tercera, dispone que la composición de las Comisiones Locales y Provinciales se modificará en función del resultado de las elecciones agrarias. No se olvide que según el artículo 4.3 de la Ley, los vocales en representación de los propietarios de tierras sujetas al régimen de ordenación de pastos y los representantes de los ganaderos adjudicatarios de los mismos, serán nombrados por el pleno del Ayuntamiento a propuesta de las Organizaciones Profesionales Agrarias más representativas. Por tanto, la representatividad de estas Organizaciones quedará determinada tras cada una de las elecciones agrarias que se celebren. Por tanto, el resultado electoral influirá en la capacidad de propuestas para el nombramiento de los vocales en función de la representatividad que hayan obtenido en los comicios electorales agrarios. Por ese, una vez celebradas las elecciones, según esta disposición transitoria tercera, las Comisiones Locales y Provinciales adaptarán la representación al resultado electoral.

La disposición transitoria cuarta, declara que a la entrada en vigor de esta Ley se declaran subsistentes los polígonos y las adjudicaciones de pastos existentes, pudiendo no obstante posteriormente, la Comisión Local de Pastos efectuar las modificaciones procedentes.

Mientras no sean aprobadas las respectivas Ordenanzas Pastos, la disposición transitoria quinta dispone que continuaran en vigor las aprobadas al amparo del Decreto I256/1969, de 6 de junio, por el que se aprueba el Reglamento de Pastos, Hierbas y Rastrojeras.

La disposición derogatoria única, no deroga el Decreto 1256/1969, de 6 de junio, por el que se aprueba el Reglamento de Pastos, Hierbas y Rastrojeras, por tratarse de normativa del Estado, poder central, vigente en cuanto reúna la condición de Derecho supletorio al de las Comunidades Autónomas con competencias en esta materia. En todo caso, la aplicación parcial del Decreto I256/1969, de 6 de junio, por el que se aprueba el Reglamento de Pastos,

${ }^{94}$ Distinta es la opinión de De PABlo Contreras, P., Curso de Derecho Civil I. Derecho Privado. Derecho de la Persona, Editorial Colex, I998, p. II4 : «Aquí la carencia de regulación se da en un extremo que podría haber sido regulado por el Derecho autonómico, al tener la Comunidad competencia para ello, por lo que la disponibilidad de la materia por el ordenamiento suplido obliga a la aplicación de la norma suplente conforme a los criterios de interpretación e integración propios de aquel». 
Hierbas y Rastrojeras, en el ámbito territorial de la Comunidad Autónoma CastellanoManchega, se realizará con las correspondientes adecuaciones establecidas en la presente Ley pastueña.

Por el contrario, queda expresamente derogado, a la entrada en vigor de la presente Ley, el Capítulo I del Título III de la Ley 9/1985, de I8 de diciembre, de Tasas de la Comunidad Autónoma de Castilla-La Mancha, actualmente vigente conforme a lo dispuesto en la Disposición Transitoria I ${ }^{a}$ de la Ley 3/I990, de I8 de mayo de Tasas y Precios Públicos.

Por último existen dos disposiciones finales. La primera se refiere a la entrada en vigor de la Ley: La presente Ley entrará en vigor a los veinte días de su publicación en el Diario Oficial de Castilla-La Mancha. Esta «vacatio legis» posibilitará el conocimiento material de la Ley y la adopción, en su caso, de medidas necesarias para su aplicación. La segunda Disposición Final contempla autorizaciones y mandatos dirigidos a la producción de normas jurídicas. Concretamente, el Consejo de Gobierno de la Junta de Comunidades de Castilla-La Mancha, mediante Decreto podrá revisar y actualizar las sanciones consistentes en multas. Aún cuando no se disponga en este lugar, en todo caso, el Consejo de Gobierno de la Junta de Comunidades de Castilla-La Mancha, en el ámbito de sus competencias, se encuentra habilitado por el bloque de constitucionalidad para desarrollar reglamentariamente esta Ley, aspecto este que a mi juicio sería conveniente.

\section{A modo de conclusión: la dispensable legislación especial de ordenaicón de pastos, hierbas y rastrojeras.}

Tras la abolición de los privilegios de la Mesta y del Decreto de las Cortes de Cádiz sobre cerramiento de fincas, el pastoreo en fundos ajenos, al margen de las servidumbres y comunidades de pastos reguladas en el Código Civil, se ha sustentado sobre bases precarias ${ }^{95}$, dado el carácter consuetudinario de las normas que regulaban el aprovechamiento de los pastos y a las que hace referencia el propio preámbulo de la Ley de aprovechamiento de hierbas, pastos y rastrojeras, de 7 de octubre de 1938 : «Las perturbaciones que el actual régimen de aprovechamientos de hierbas, pastos y rastrojeras producen en los términos municipales de explotación agrícola parcelada, impone la necesidad de una ordenación que, respetando normas consuetudinarias basadas en características comarcales, coordine los intereses agrícolas y ganaderos, atendiendo al mayor rendimiento, de acuerdo con el interés nacional».

Tras la Guerra Civil, se impuso como una realidad social la supervivencia de la comunidad de pastos en muchos pueblos, con sus aprovechamientos colectivos por encima de las normas legales ${ }^{96}$, siendo necesario aprobar para su ordenación la Ley de I938, en basa a la cual, se reguló el aprovechamiento de los pastos fundamentalmente en las ordenanzas municipales $^{97}$, hasta que por Decreto de 6 de junio de 1969 , se aprobó el Reglamento de

\footnotetext{
${ }^{95}$ NIETO,A., Pastos, hierbas y rastrojeras, Valladolid, I959, pp. 212 y ss.

${ }^{96}$ BELTRAN DE HEREDiA, La comunidad de bienes en el Derecho español, i954, para quien a pesar de la especialidad de estos aprovechamientos, se trata de una de las formas donde se manifiesta todavía en nuestro Derecho la antigua «comunidad en mano común de tipo germánico».

${ }^{97}$ El artículo primero de la Ley de 7 de octubre de 1938, establece que: «Las Juntas Locales de Fomento pecuario propondrán a la aprobación de las Juntas Provinciales correspondientes, en el plazo de noventa días, a partir de la publicación de la presente Ley, las Ordenanzas que deban regir el
} 
Pastos, hierbas y rastrojeras, que significó el punto de partida de una regulación más uniforme. Han transcurrido más de 33 años de la aprobación del Reglamento 1969, y las circunstancias políticas, sociales y económicas de España, integrada en la Unión Europea, son muy distintas. Por tanto, es preciso reflexionar sobre la necesidad o no de un régimen de ordenación de pastos, y si se llega a la conclusión de que tal régimen resulta necesario, sobre qué bases debe vertebrarse el mismo.

Para este propósito, resulta ilustrativo la atenta lectura del preámbulo de la Ley I5/2002 de la Comunidad de Aragón, en el cual se plantean algunas cuestiones cruciales sobre la vigencia y necesidad del régimen jurídico del aprovechamiento de los pastos.

Varias son las razones que, según la exposición de motivos del texto legal aragonés, conducen a considerar inadecuado un sistema de ordenación de pastos intervencionista y generalista. En primer lugar, se dice que es opinión generalizada que la Ley y el Reglamento de Pastos estatales, responden a planteamientos desfasados, sus disposiciones son arcaicas y precisan de una necesaria adaptación a los nuevos tiempos. Pero no es ésta la única razón por la cual se aplican menos. Además existen otras razones que conducen a esa inaplicación:

Primeramente, ha de tenerse presente las modificaciones organizativas propias impuestas por la nueva legislación de Cámaras Agrarias, que han supuesto la desaparición de la estructura sobre la que se asentaba la ordenación de pastos. En este sentido, el profesor De la Cuesta $^{98}$, ya había señalado como el paso del tiempo había conducido a una situación de progresiva pérdida de aplicabilidad de la Ley de 7 de octubre de I 938 y de su reglamento de I969, debido fundamentalmente -además de al cambio de las técnicas de cultivo, cada vez menos compatibles con el aprovechamiento generalizado de los llamados pastos secundariosa la inoperancia de los órganos que tenían legalmente encomendada la gestión de esos aprovechamientos de pastos.

En segundo lugar, se asegura, no sin razón, que la aplicación de la regulación del modelo diseñado en la disposiciones de ordenación de pastos estatal, ocasiona conflictos entre agricultores y ganaderos al quedar encorsetados en el sistema reglado e intervencionista contenido en la Ley de pastos, hierbas y rastrojeras de I938 y su Reglamento ${ }^{99}$ de I969. Su aplicación supone la exclusión del precio de los pastos del libre mercado, puesto que se dan unos precios que están claramente por debajo de los del mercado libre.

En tercer lugar, ha de determinarse en qué medida la ejecución del sistema normativo de ordenación del aprovechamiento de los pastos establecido por la Ley de Pastos de 1938 y su Rglamento, puede originar un incumplimiento de las obligaciones en algunos regímenes de ayudas procedentes de la Política Agrícola Común. En otras palabras, ha de plantearse las consecuencias derivadas del modelo de ayudas públicas constituido por la

aprovechamiento de pastos y rastrojeras de sus términos municipales respectivos, con sujeción a las normas generales que establezca el ministerio de Agricultura».

$9^{8}$ De LA Cuesta SAEnZ, J.M ${ }^{a}$, Legislación agraria de Castilla y León, en «Derecho Agrario Autonómico», Universidad de Oviedo, Oviedo, I99ı, p. I9० у I9ı.

${ }^{99}$ De conformidad con el artículo 8I al Decreto I256/ı969, de 6 de junio, por el que se aprueba el Reglamento de pastos, hierbas y rastrojeras, en: «Las Juntas provinciales de Fomento pecuario determinarán anualmente, con la debida antelación y en todo caso cuatro meses antes del comienzo del nuevo año ganadero, los precios mínimos y máximos que durante el mismo habrán de regir para la hectárea de pastos en cada zona ganadera de su provincia, en consonancia con la calidad de aquellos. Dicho acuerdo podrá ser recurrido, de conformidad con lo que establece en el artículo io4 de este Reglamento». 
P.A.C. en relación con la ejecución normativa estatal de ordenación del aprovechamiento de los pastos.

El existente sistema estatal de ordenación de pastos, entra, en ocasiones, en conflicto con el sistema de ayudas establecido en el contexto de la PAC al resultar «prácticamente incompatible» la adecuada gestión de las ayudas de la P.A.C. con un sistema general de ordenación de los pastos que no tenga en cuenta las circunstancias específicas en cada caso particular. Para la percepción de las ayudas de la P.A.C. hay que cumplir unos requisitos necesarios y evitar caer en penalizaciones por el modo y tiempo de aprovechar los pactos, siendo necesario cumplir un calendario, conocer las limitaciones en las formas de aprovechamiento de los pastos, asumir las prohibiciones de aprovechamiento ganadero existentes, aspectos estos que sólo conoce con la precisión y seguridad debida el beneficiario de cada ayuda de la PAC como titular del aprovechamiento agrícola de la finca.

En este sentido, el sistema estatal de ordenación de pastos existente, puede conducir al incumplimiento de las obligaciones impuestas en el régimen de ayudas públicas determinado con arreglo a la PAC. Por tanto, para evitar incumplimientos no achacables al beneficiario de ese régimen de ayudas, el beneficiario ha de controlar el correcto cumplimiento de las obligaciones que ha asumido cuando se le concedieron las ayudas.

Pensemos en ciertas ayudas por superficie en las que se establecen diversas limitaciones respecto al uso de las superficies agrarias sometidas a retiradas de la producción o destinadas a barbecho. En esas limitaciones, se circunscriben al aprovechamiento ganadero y a la fechas en que puede efectuarse.

El aprovechamiento ganadero de los rastrojos, cuyo cultivo ha sido declarado y recolectado, dificulta tanto los controles como las inspecciones en el campo ${ }^{\text {ioo }}$, lo cual puede originar una imposición de sanciones o penalizaciones al beneficiario de las ayudas por actuaciones de las que pudiera no ser responsable puesto que quedan fuera de su esfera de decisión y control.

También en el sistema de ayudas agroambientales pudiera suceder algo parecido. Las «ayudas agroambientales» al estar ligadas a la tierra y no al ganado, requieren para su percepción, el respeto a determinadas cargas ganaderas, que pudieran verse vulneradas por conductas de las que puede no ser responsable el perceptor de las ayudas al quedar al margen de su decisión y control.

No se ha de olvidar que con los nuevos objetivos de protección ambiental de la P.A.C., las ayudas están cada vez más vinculadas al cumplimiento de unas reglas de carácter ambiental o «buenas prácticas agrarias» que deben cumplirse en el ejercicio de las actividades agrícolas y ganaderas.

En el marco del Reglamento (CE) I257/I999, del Consejo, de I7 de mayo, sobre ayudas al desarrollo rural a cargo del Fondo Europeo de Orientación y Garantía Agraria

${ }^{\text {roo }}$ En el preámbulo de la Ley $15 / 2002$, de 27 de junio, por la que se deja libre de ordenación el aprovechamiento de los pastos en la Comunidad deAragón, se expresa que: «En concreto, dentro del sistema de ayudas por superficie, se establecen diversas limitaciones respecto al uso de las superficies agrarias sometidas a retiradas de la producción o destinadas a barbecho; las limitaciones citadas se circunscriben al aprovechamiento ganadero y a las fechas en que el mismo puede efectuarse. En ese mismo régimen específico de ayudas, viene sucediendo que el aprovechamiento ganadero de los rastrojos correspondientes a parcelas cuyo cultivo ha sido declarado y recolectado dificulta, cuando no hace imposible , las inspecciones y controles en campo» 
(FEOGA), en el que establece el marco de las ayudas comunitarias a favor de un desarrollo rural sostenible, España ha aprobado el Real Decreto 708/2002, de I9 de julio, por el que se establecen medidas complementarias al Programa de Desarrollo Rural para las medidas de acompañamiento de la Política Agrícola Común. En su Anexo I, se contienen las denominada prácticas agrarias habituales, considerando como tales: «las técnicas normales de explotación que responsablemente aplicaría un agricultor en la zona donde ejerza su actividad».

Entre las prácticas beneficiosas para el Medio Ambiente, el punto 9.4 del Anexo I, establece que la carga ganadera de las superficies forrajeras de la explotación no podrá sobrepasar los siguientes límites:

a) «Comarcas con pluviometría anual menor de 600 milímetros: I UGM/hectárea y año.

b) Comarcas con pluviometría anual igual o mayor de 600 milímetros y menor de 800 milímetros: I,50 UGM/hectárea y año.

c) Comarcas con pluviometría anual igual o mayor de 800 milímetros: 2 UGM/hectárea y año.»

Por otra parte en el Anexo II, en el punto 9 referido a la gestión integrada de las explotaciones, se establecen compromisos de las medidas de actuación sobre las zonas de pastos y rastrojeras:

Respeto a cargas ganaderas máximas y mínimas establecidas.

No superar la carga ganadera de la explotación fijada en el plan de gestión de la explotación, durante los años que dure el compromiso.

Aprovechamiento racional de las rastrojeras y resto de superficies pastables, respetando el calendario de pastoreo.

No levantar los rastrojos hasta cinco meses después de la recolección de las superficies de cereales integrantes de su explotación agrícola que figure en su declaración anual de cultivos herbáceos.

Dejar el menos el 50\% de la paja de los cultivos de cereales sobre el terreno.

Recoger las cuerdas del atado de pacas de paja, heno o ensilado utilizadas para alimentación del ganado, almacenándolas en la explotación en sacos hasta su retirada. extensificadas.

Realizar un aprovechamiento de pastos racional contemplando las superficies

Pastoreo con razas autóctonas con un $20 \%$ adicional en la prima correspondiente, cuando éste se realice con efectivos al menos en su $75 \%$ de razas autóctonas inscritas en los correspondientes Libros de Registro de las Razas Oficiales.

Las buenas prácticas son de obligado cumplimiento para la concesión de las ayudas en zonas desfavorecidas y las primas a medidas agroambientales. Para hacer posible el cumplimiento de las buenas prácticas agrarias y evitar incumplimientos no achacables al titular de las ayudas de la P.A.C., resulta preciso poner en manos del sujeto al régimen de 
ayudas, los medios para el autocontrol del correcto cumplimiento de las obligaciones asumidas como beneficiario de las ayudas.

Por tanto, habrá que acudirse a dejar libre de ordenación el aprovechamiento de los pastos a través de un sistema en el que las partes libremente acuerden como van a aprovecharse los pastos. De esta manera, los agricultores y ganaderos, teniendo presente la circunstancias singulares de cada caso, pueden determinar el modo de aprovechar los pastos, respetando, para obtener las correspondientes ayudas de la P.A.C., los límites marcados por las condiciones impuestas por las buenas prácticas agrarias.

En suma, los pastos no quedan libres de toda ordenación, sino que existe un sistema de ordenación, en el que la Ley es la que las partes, en uso de su autonomía de la voluntad, pacten, acordando libremente como va a realizarse su aprovechamiento, en atención y consideración a las específicas y peculiares circunstancias que converjan en cada caso ${ }^{\text {Ior }}$.

En este sentido, ya se había pronunciado el profesor De la Cuesta, quien ante la progresiva inaplicación de la legislación estatal, y ante la falta de calificaciones reales típicas, como la servidumbre o la comunidad, y donde no hubiese un régimen consuetudinario claro y asentado, consideró «conveniente que tales aprovechamientos corresponde al titular de las facultades de goce y disfrute del fundo de que se trate, aplicando las reglas generales del Código Civil sobre frutos y en último término la presunción de libertad de los fundos consagrada por la jurisprudencia, y en consecuencia que su aprovechamiento por otros sujetos debería tener base contractual. De ese modo, los titulares que cediesen tales aprovechamientos, lo harían en régimen de contratación, percibiendo una contraprestación por la correlativa limitación de sus facultades.» ${ }^{102}$.

Ahora bien, hay que señalar que dejar libre de ordenación el aprovechamiento de los pastos junto a las posibles ventajas aporta también efectos que pueden resultar desfavorables. Es indudable, como he señalado lo ventajoso que puede resultar para más racional aprovechamiento de pastos, el hacerlo compatible con el cumplimiento de las obligaciones derivadas de los sistemas de ayudas agrarias de la P.A.C. Pero también puede conducir que el resultado sea dejar el pasto sin aprovechar al no llegar a acuerdos, los agricultores y los ganaderos, en cuyo caso, entiendo que cabe la aplicación en cada municipio o lugar de los respectivos usos y costumbres que en aquellos se sigan teniendo siempre que no afecten a las obligaciones del agricultor beneficiario, derivadas de los sistemas de ayudas agrarias de la P.A.C.

${ }^{\text {ror }}$ En este sentido la Ley I5/2002, de 27 de junio, queda libre de ordenación el aprovechamiento de los pastos, hierbas y rastrojeras en la Comunidad Autónoma de Aragón. Trata de abordar un nuevo marco que componga los intereses enfrentados de agricultores y ganaderos, dejando libre de ordenación el aprovechamiento de los pastos en la Comunidad Autónoma de Aragón y diseñando un régimen de libre contratación, en cuyo seno los agricultores y los ganaderos pactasen las condiciones del aprovechamiento de los pastos, si bien mediante una transición suave desde el esquema corporativo previsto en la normativa estatal que estaba vigente. Vide su artículo único, en base al cual lo que se deja libre es la ordenación del aprovechamiento, no el propio aprovechamiento de los pastos, hierbas y rastrojeras, esto es, se adopta un sistema en el que las partes, en uso de su autonomía de la voluntad, son las que libremente acuerdan como va a realizarse el aprovechamiento de los pastos.

${ }^{\text {Ior }}$ DE LA CUeSTA SAENZ, J.Ma ., Legislación agraria de Castilla y León, en «Derecho Agrario Autonómico», Universidad de Oviedo, Oviedo, I99ı, p. I90 y I9I. 